\title{
Star-Shaped Molecules Containing Polyalkynyl Groups with Metal Moieties on Benzene and Triphenylene Cores
}

\author{
Chiung-Cheng Huang, ${ }^{\text {[a] }}$ Ying-Chih Lin, ${ }^{*[a]}$ Ping-Yu Lin, ${ }^{[b]}$ and Yu-Ju Chen ${ }^{[b]}$
}

Keywords: Alkynes / Palladium / Platinum / Gold / Heterometallic complexes / Luminescence

A series of star-shaped molecules with a silyl group and an aromatic core surrounded by extended $\pi$ conjugative arms has been synthesized by the use of Sonogashira coupling methods. They show excellent fluorescence intensity with high quantum yield. These molecules undergo desilylation in the presence of $n \mathrm{Bu}_{4} \mathrm{NF}$ to give terminal polyalkynyl compounds. By incorporating metal moieties such as palladium, platinum and gold into these compounds, star-shaped mole- cules can be obtained. Photophysical properties of these molecules are investigated spectroscopically in solution. These star-shaped molecules are characterized by IR, NMR $\left({ }^{1} \mathrm{H},{ }^{31} \mathrm{P}\right.$ and $\left.{ }^{13} \mathrm{C}\right)$ spectroscopy, as well as MALDI-TOF mass spectrometry.

(@ Wiley-VCH Verlag GmbH \& Co. KGaA, 69451 Weinheim, Germany, 2006)

\section{Introduction}

Since the past decade, there has been a blooming growth in the development of the chemistry of carbon-rich metalcontaining systems, in particular those with long sp carbon chain. ${ }^{[1]}$ Such a rapid growth is partly assisted by the urgent demand for new materials in molecular electronics as a result of the inherent limit of the present semiconductor technology. The alkynyl group, with its linear geometry, structural rigidity, extended $\pi$-electron delocalization, and ability to interact with metal centers through $\mathrm{p}_{\pi}-\mathrm{d}_{\pi}$ overlap, has been an attractive candidate to serve as building blocks for the construction of carbon-rich metal-containing materials that possess potential applications as optical nonlinearity, ${ }^{[2]}$ electrical conductivity, ${ }^{[3]}$ luminescence ${ }^{[4]}$ and liquid crystallinity. ${ }^{[5]}$

Early works on metal alkynes involve those of polymeric nature, which precluded further purification and characterization. Hagihara and co-workers reported the first soluble polyynylplatinum and -palladium complexes. ${ }^{[6]}$ Subsequent reports on metal-containing polyynes provided important contributions in this area. ${ }^{[7]}$ Despite all these important works, studies on these polymeric systems present difficulties such as the exact arrangement of the structure, molecular-weight distribution, heterogeneity of samples, reproducibility, and many others. All of these would render a direct understanding of the structure-property relationship and the fundamental understanding on the spectroscopic origin of these chromophores less straightforward and less

[a] Department of Chemistry, National Taiwan University, Taipei, Taiwan

[b] Institute of Chemistry, Academia Sinica,

Nankang, Taipei, Taiwan

Fax: +886-2-23636359

E-mail: yclin@ntu.edu.tw amenable to study. Recent interest in alkynylpalladium(II) and -platinum(II) chemistry has been extended toward platinum-containing hyperbranched molecules and organometallic dendrimers. Stang ${ }^{[8]}$ and Takahashi ${ }^{[9]}$ have shown that 1,3,5-triethynylbenzene could be used as a building block for organoplatinum dendrimers. Yam and her coworkers ${ }^{[10]}$ have explored the luminescence properties of a series of branched alkynyl palladium(II) and alkynylplatinum(II) complexes. With regard to hexaethynylbenzene, Vollhardt et al. first reported its synthesis and derivatives at high-temperature Sonogashira conditions in $1986 .{ }^{[11]}$ Recently, Beck ${ }^{[12]}$ have utilized hexaethynylbenzene as a building block to construct star-shaped molecules containing hexa-platinum and hexa-iron. Despite the growing interests and extensive studies in alkynylmetal compounds in the past decade or so, relatively less attention was focused on the exploration and exploitation of dendritic molecules containing more metal moieties as luminescent materials. Herein, we report the properties of a series of organic starshaped molecules with four, five and six arms, and then incorporate palladium, platinum and gold metal moieties into them to extend the polyethynylbenzenes in the direction of the long conjugated polyyne system to investigate the properties of these metal acetylide molecules.

\section{Results and Discussion}

Synthetic methodologies used for the construction of poly(silylethynyl)benzenes rely on two approaches described as divergent and convergent strategies. The compounds 14 could be prepared by convergent method by a simple onepot reaction involving Pd-catalyzed alkynylation of halogenated arenes with 1-ethynyl-4-[2-(triisopropylsilyl)ethynyl]benzene $(\mathbf{A})^{[13]}$ under the condition of Sonogashira coup- 


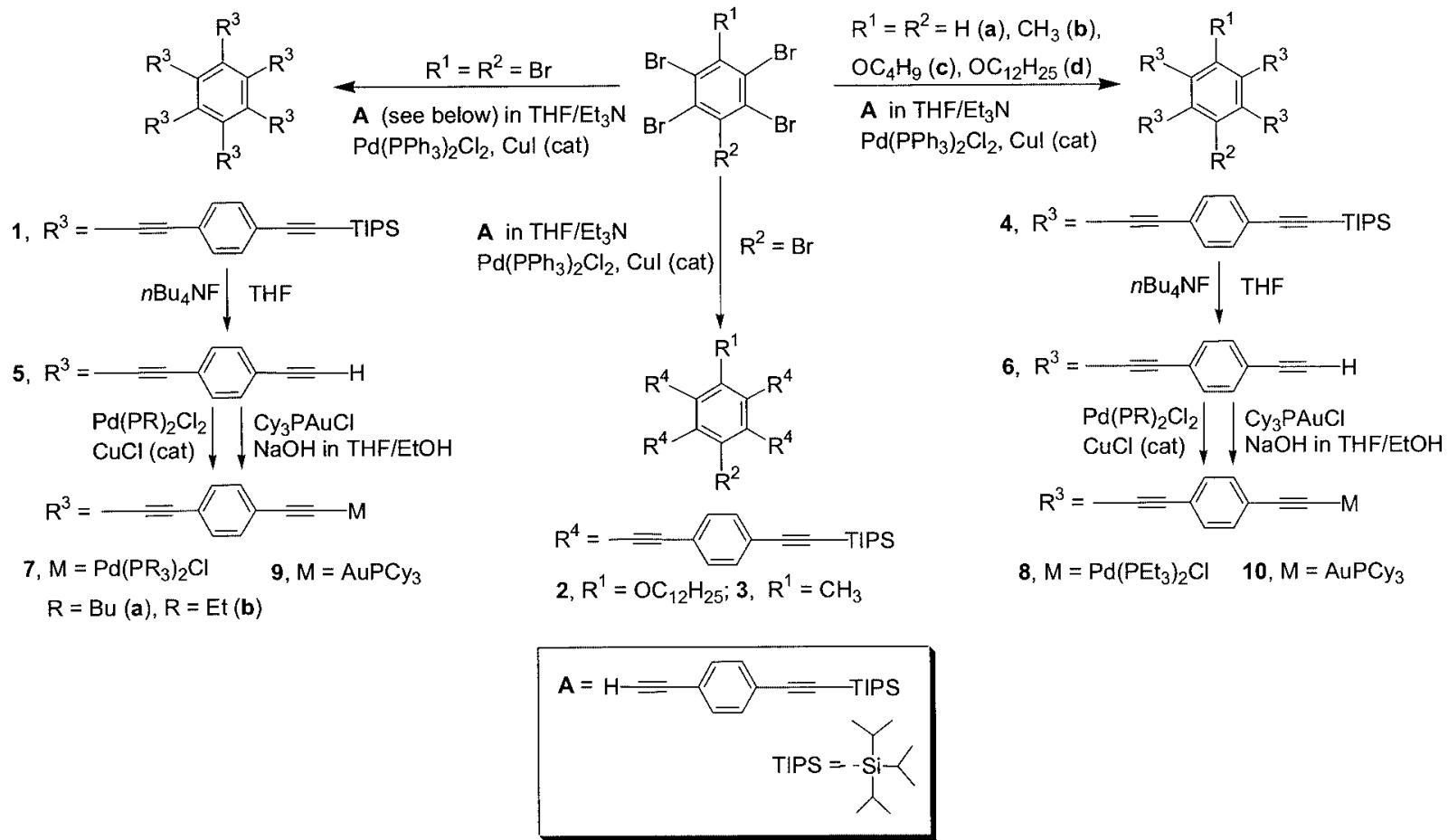

Scheme 1.

ling reaction. ${ }^{[14]}$ The inverse cross-coupling reaction of (4iodophenyl)ethynyltrimethylsilane with ethynylated arenes also afforded the desired poly(silylethynyl)benzenes compound on divergent approach. However, the intermediate obtained in the divergent method, hexaethynylbenzene could turns brown slowly in the absence of air and rapidly in its presence. ${ }^{[11]}$ Therefore, it is not convenient to utilize it as good precursors for subsequent Sonogashira coupling reaction to form poly(silylethynyl)benzenes. For this reason, the poly(silylethynyl)benzenes $\mathbf{1 - 4}$ were efficiently prepared by the convergent approach. The preparation of 1-4 commenced with tetra-, penta- or hexa-halogenated arenes and excess $\mathbf{A}$ as outlined in Scheme 1. Compared with the reported preparation of the similar molecules, ${ }^{[15]}$ our preparation uses only 1.1-1.25 equiv. of $\mathbf{A}$, and the poly(silylethynyl)arenes 1-4 are obtained in $50-90 \%$ yield. Desilylation of poly(silylethynyl)benzene $\mathbf{1}$ and $\mathbf{4}$ with $n \mathrm{Bu}_{4} \mathrm{NF}$ gave the compounds $\mathbf{5}$ and $\mathbf{6}$, respectively, mostly in quantitative yield with multiple terminal alkynyl groups.

In the reaction of 5 and $\mathbf{6}$ with trans- $\mathrm{Pd}\left(\mathrm{PR}_{3}\right)_{2} \mathrm{Cl}_{2}(\mathrm{R}=$ $\mathrm{Et}, \mathrm{Bu}$ ), only a four- or sixfold equivalent of Pd complex was dissolved in THF in the reaction mixture for the formation of the desired product. Multiple Pd metal moieties were added to all terminal carbon atoms of alkyne. The reaction was carried out in the presence of $\mathrm{CuCl}$ catalyst and $\mathrm{Et}_{2} \mathrm{NH}$ to yield the palladium acetylide complex 7 . After stirring at room temperature overnight the reaction mixture was processed by chromatography to yield the expected air- and moisture-stable palladium complex in good yield $(>70 \%)$. We note that Yam and her co-workers ${ }^{[10]}$ have reported that excess trans- $\mathrm{M}\left(\mathrm{PEt}_{3}\right)_{2} \mathrm{Cl}_{2}(\mathrm{M}=\mathrm{Pd}, \mathrm{Pt})$ was required in the preparation of the branched palladium ace-
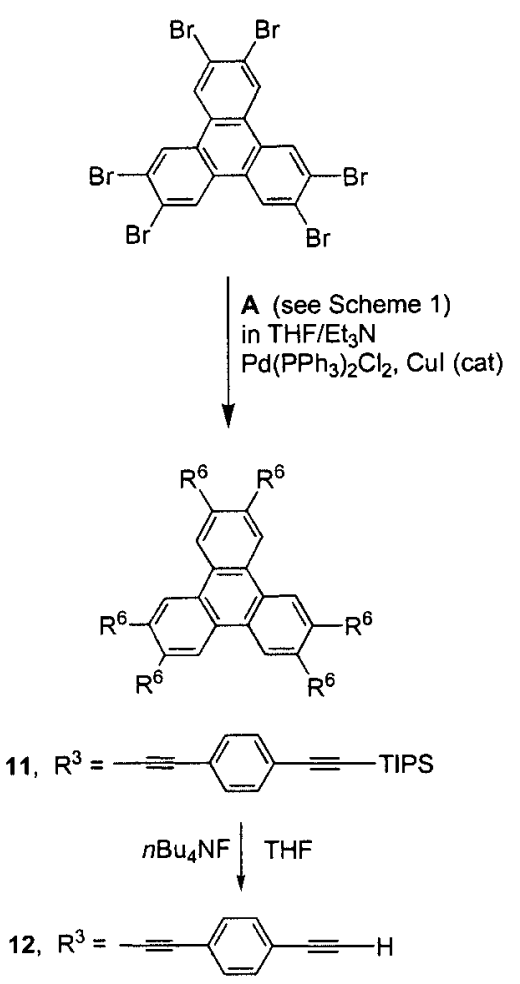

$\mathrm{Pd}(\mathrm{PR})_{2} \mathrm{Cl}_{2} \mid \mathrm{Cy}_{3} \mathrm{PAuCl}$ $\mathrm{CuCl}$ (cat) $\sqrt{\mathrm{NaOH}}$ in $\mathrm{THF} / \mathrm{EtOH}$

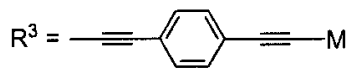

13, $M=P d\left(P B u_{3}\right)_{2} \mathrm{Cl} \quad 14, M=\mathrm{AuPCy}_{3}$

Scheme 2 . 
tylide complexes in the presence of copper(I) catalyst in order to decrease the formation of undesirable insoluble oligomeric materials. They carried out these reactions in $\mathrm{CH}_{2} \mathrm{Cl}_{2}$. In our cases, the reaction in $\mathrm{CH}_{2} \mathrm{Cl}_{2}$ gave incomplete incorporation of the metal moieties affording threeor four-substituted product. However, the reaction in THF generally gave much better yield because the organic starting material has a higher solubility in THF. Using the preparation method of gold acetylide in the literature, ${ }^{[16]}$ the gold complexes $\mathbf{9}$ and $\mathbf{1 0}$ are obtained in THF solution from compound $\mathbf{5}$ and $\mathbf{6}$, respectively with a four- or sixfold of $\left(\mathrm{Cy}_{3} \mathrm{P}\right) \mathrm{AuCl}$ in the presence of a strong base $\mathrm{KOH}$. Consequently, we believe that the solvent plays a crucial role in the preparation of alkynylmetal. In addition, complexes 1114 with triphenylene as the core have been synthesized by similar preparation method (Scheme 2).

\section{Spectroscopic Characterization}

These star-shaped molecules are characterized by ${ }^{1} \mathrm{H}$, ${ }^{13} \mathrm{C},{ }^{31} \mathrm{P}$ NMR, mass and IR spectroscopy and give satisfactory elemental analysis. The high symmetry of compound 1, with twelve acetylenic groups and six silyl groups, is manifested by simple signals in the ${ }^{1} \mathrm{H}$ and ${ }^{13} \mathrm{C}$ NMR spectra. In the ${ }^{1} \mathrm{H}$ NMR spectrum of $\mathbf{1}$, there is only one set of two doublet resonance at $\delta=7.51$ and $7.47 \mathrm{ppm}$ with $J_{\mathrm{H}-\mathrm{H}}=$ $8.5 \mathrm{~Hz}$ in the aromatic region. In addition to the ${ }^{13} \mathrm{C} \mathrm{NMR}$ signals of the triisopropylsilyl group typically at $\delta=18.7$, $11.3 \mathrm{ppm}$, five signals (one for the benzene core and four for the $\mathrm{C}_{6} \mathrm{H}_{4}$ groups) are observed in the region of $\delta=134$ 124 and four signals for the acetylide carbon atoms are observed at $\delta=106.5,99.4,93.6$ and $88.8 \mathrm{ppm}$ indicating the $C_{6}$ symmetry. Mass spectra of star-shaped molecules with triisopropylsilyl groups can not be determined by traditional techniques such as FAB and EI. Therefore, MALDITOF technique is used to obtain the mass spectra of these compounds. MALDI-TOF mass spectra were obtained using DHB (2,5-dihydroxybenzoic acid) as matrix. The protonated molecular ion $[\mathrm{M}+\mathrm{H}]^{+}$appeared as the parent ion in the spectra of compounds $\mathbf{1} \mathbf{- 4}$ and $\mathbf{1 1}$.

The ${ }^{1} \mathrm{H}$ NMR spectrum of palladium complexes 7 shows only one set of two doublet resonance at $\delta=7.48$ and 7.21 ppm with ${ }^{3} J_{\mathrm{H}-\mathrm{H}}=8.2 \mathrm{~Hz}$ in the aromatic region and four broad resonances in the region of $\delta=2.0-0.9 \mathrm{ppm}$ are rationally assigned to the butyl protons on the $\mathrm{P} n \mathrm{Bu}_{3}$ ligands. No signal for acetylenic proton was detected, eliminating the possibility of the existence of partially substituted molecules. In the ${ }^{31} \mathrm{P}$ NMR spectrum, only one singlet signal was observed at $\delta=10.80 \mathrm{ppm}$. The ${ }^{13} \mathrm{C}$ resonances of the alkynyl carbon atoms bound to the palladium are at $\delta$ $=106.27 \mathrm{ppm}$ with ${ }^{2} J_{\mathrm{C}-\mathrm{P}}=5.3 \mathrm{~Hz}$ and $101.62{ }^{2} J_{\mathrm{C}-\mathrm{P}}=$ $15.6 \mathrm{~Hz}$, respectively. Two singlet resonances of internal alkynyl carbon atoms are located at $\delta=99.68$ and 88.55 ppm. These data are consistent with other palladium acetylide complexes in the literature. ${ }^{[10 a]}$

The ${ }^{13} \mathrm{C}$ NMR spectra of the gold complexes 9 and $\mathbf{1 0}$ display two doublets at $\delta=140-139\left({ }^{2} J_{\mathrm{C}-\mathrm{P}}=131 \mathrm{~Hz}\right)$ and $\delta=103-104\left({ }^{2} J_{\mathrm{C}-\mathrm{P}}=24 \mathrm{~Hz}\right) \mathrm{ppm}$, which are assigned to the $\alpha$ - and $\beta$-carbon atoms of the acetylide ligand, respectively. ${ }^{[17]}$ The ${ }^{31} \mathrm{P}$ NMR spectra of $\mathbf{9}$ and $\mathbf{1 0}$ reveal singlet resonances at $\delta=56.8$ and $56.9 \mathrm{ppm}$, respectively, which slightly shift downfield from that of $\mathrm{Au}\left(\mathrm{PCy}_{3}\right) \mathrm{Cl}$ at $\delta=$ $55.2 \mathrm{ppm}$.

The IR spectra of all organic compounds containing silyl and terminal alkynyl groups show one stretching band at around $2190 \mathrm{~cm}^{-1}\left(v_{\mathrm{C} \equiv \mathrm{C}}\right)$ and terminal acetylenic ends $(\equiv \mathrm{CH})$ near $3286 \mathrm{~cm}^{-1}$. Additionally, after incorporating metal moieties, these compounds exhibit other stretching band at around $2090 \mathrm{~cm}^{-1}$. It is probably due to $\pi$ backbonding from metal centers to reduce the stretching frequency of the $\mathrm{C} \equiv \mathrm{C}$ bond adjacent to the transition metal. With regard to the mass spectra of these metal acetylide complexes, $\mathbf{8}$ and $\mathbf{1 0}$ with four arms show parent ion [M + $\mathrm{H}]^{+}$consistent with their formulation in the FAB mass spectra. Nevertheless, metal acetylide complexes with six arms can not been detected by FAB or MALDI-TOF mass.

\section{Heterometallic Polynuclear Complexes}

Platinum acetylide complex $\mathbf{1 5}$ was prepared by the reaction of compound $\mathbf{A}$ and cis- $\mathrm{Pt}\left(\mathrm{PEt}_{3}\right)_{2} \mathrm{Cl}_{2}$ in the presence of $\mathrm{CuCl}$ catalyst in $\mathrm{Et}_{3} \mathrm{~N} /$ toluene. ${ }^{[18]}$ Subsequent reaction of 5 with excess of $\mathbf{1 5}$ in the presence of a $\mathrm{CuCl}$ catalyst in THF/diethylamine generated the pure complex 16, which undergoes deprotection in the presence of tetrabutylammonium fluoride to afford complex $\mathbf{1 7}$ containing six terminal alkynes. The reaction of $\mathbf{1 7}$ with 6 equiv. of $\left(\mathrm{Cy}_{3} \mathrm{P}\right) \mathrm{AuCl}$ in the presence of excess of $\mathrm{KOH}$ give the heterometallic complex 18 containing six gold and six platinum metal atoms (Scheme 3).

The ${ }^{31} \mathrm{P}$ NMR spectra of $\mathbf{1 6}$ and $\mathbf{1 7}$ show both a singlet resonance at $\delta=11.78$ and $11.80 \mathrm{ppm}$, respectively, indicative of highly symmetrical structure of the molecules. Platinum satellites with ${ }^{1} J_{\mathrm{Pt}-\mathrm{P}}=2359 \mathrm{~Hz}$, which is characteristic of a trans-P-Pt-P configuration, are observed in the ${ }^{31} \mathrm{P}$ NMR spectrum. ${ }^{[19]}$ In the ${ }^{1} \mathrm{H}$ NMR spectrum of 17 , four sets of coupled doublet resonances at $\delta=7.45-7.17 \mathrm{ppm}$ with $J_{\mathrm{H}-\mathrm{H}}=8.2 \mathrm{~Hz}$ are located in the aromatic region and the singlet resonance of the terminal alkyne protons is observed at $\delta=3.09 \mathrm{ppm}$. In the IR spectra, the $v_{\mathrm{C} \equiv \mathrm{C}}$ stretching band appears at 2093, $2195 \mathrm{~cm}^{-1}$ and the absorption at $3286 \mathrm{~cm}^{-1}$ is assigned to the $v_{\mathrm{H}-\mathrm{C}} \equiv$ stretching vibration.

In the ${ }^{31} \mathrm{P}$ NMR spectrum of $\mathbf{1 8}$ incorporating gold moieties, the resonance at $\delta=11.76 \mathrm{ppm}\left(\mathrm{s}, J_{\mathrm{Pt}-\mathrm{P}}=2366 \mathrm{~Hz}\right)$ was almost consistent with that of complex $\mathbf{1 7}$, and the singlet peak at $\delta=56.91 \mathrm{ppm}$ is assigned to the tricyclohexylphosphane of the gold acetylide moiety. In the ${ }^{1} \mathrm{H}$ NMR spectrum similar patterns with complex $\mathbf{1 7}$ are observed in the aromatic region. No signals for acetylenic proton are detected, eliminating the possibility of partial substitution. However, the mass spectra of these metal acetylide complexes can not obtained by FAB or MALDI mass technique. 


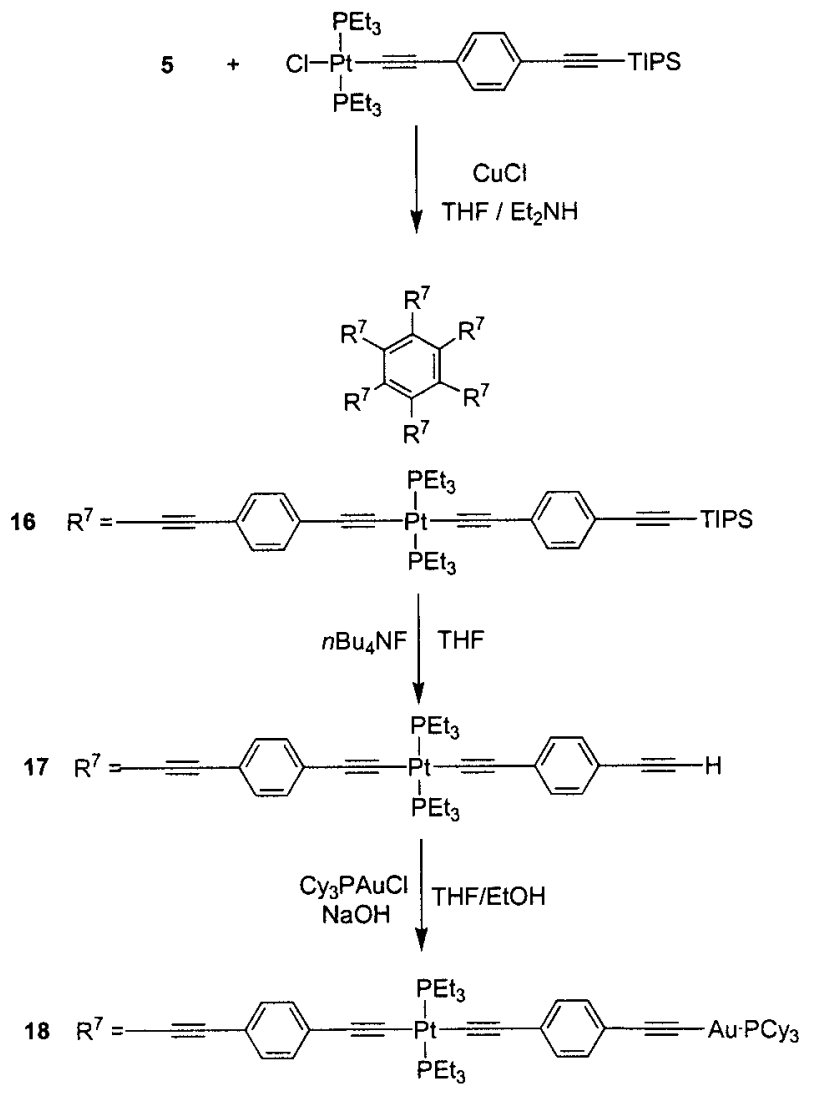

Scheme 3.

\section{Photophysical Properties}

Table 1 summarizes the photophysical data of starshaped molecules containing triisopropylsilyl group, palladium and platinum metal moieties. The emission spectra of these compounds are obtained by excitation at their longest wavelength with absorption maximums. The quantum yields were determined while the absorbance is set in the range of $0.1-0.2$ to avoid the interference of reabsorption in determining the quantum yield. The wavelength at the intersection point of the absorption spectra of the sample and the reference is taken as the excitation wavelength in determining the quantum yield.

The electronic absorption spectra of triisopropylsilylsubstituted benzene system 1-4a show that the absorption maximum $\left(\lambda_{\max }\right)$ for the lowest $\pi-\pi^{*}$ transition increases from 340 to $373 \mathrm{~nm}$ as the number of arms around the benzene core increases. The photophysical properties of the molecules presented in this report will likely arise from the extended $\pi$ conjugation and enhanced electron delocalization of these star-shaped systems. The trend is consistent with the phenylethynyl-substituted benzene system ${ }^{[20]}$ and is evidence of extended $\pi$ conjugation through the benzene core. However, $\mathbf{4 b}$ and $\mathbf{4 c}$ show a shoulder at around 398 $400 \mathrm{~nm}$ due to the electron-donation effect of the methyl group and the alkoxyl group, respectively. This phenomenon was observed for (1,4-diphenylethynyl-2,5-dialkoxy)benzene. ${ }^{[21]}$ The absorption band of compound $\mathbf{1 1}$ with triphenylene as the core displays much higher extinction coefficient with $2.9 \cdot 10^{5} \mathrm{dm}^{3} \mathrm{~mol}^{-1} \mathrm{~cm}^{-1}$ and a blue shift relative to that of compound 1 with benzene as the core. (Table 1) In general, the introduction of metal moieties makes absorption peaks $(275-420 \mathrm{~nm})$ shift to longer wavelength and displays higher extinction coefficient relative to that of $\mathbf{5}$ with terminal alkyne groups $(247-392 \mathrm{~nm})$ in THF. Much higher extinction coefficients of the absorption bands in complex 7 and $\mathbf{1 6}$ than their precursor complex, trans$\mathrm{M}\left(\mathrm{PEt}_{3}\right)_{2} \mathrm{Cl}_{2}(\mathrm{M}=\mathrm{Pd}, \mathrm{Pt}){ }^{[22]}$ and the close similarity of its absorption patterns and extinction coefficients with that of compound $\mathbf{1}$ and $\mathbf{5}$ are indicative of transitions of predominantly organic complex character. Spectroscopic studies on trans $-\left[\mathrm{L}_{2} \mathrm{M}(\mathrm{C} \equiv \mathrm{CR})_{2}\right](\mathrm{L}=$ tertiary phosphane or stibane, $\mathrm{M}=\mathrm{Ni}, \mathrm{Pd}, \mathrm{Pt})^{[23]}$ and trinuclear palladium or platinum acetylide complexes, ${ }^{[\mathrm{gd}, 10]}$ in which the absorption bands at ca. 300-370 nm were assigned as metal-to-alkynyl MLCT transitions have been reported. It is likely that the electronic absorption bands of these metal acetylide complexes would also involve metal-to-alkynyl MLCT character.

Table 1. Photophysical properties.

\begin{tabular}{llll}
\hline Compounds & Absorption spectra $\lambda_{\max }[\mathrm{nm}]\left(10^{-4} \varepsilon / \mathrm{M}^{-1} \mathrm{~cm}^{-1}\right)$ & Emission spectra $\lambda_{\max }[\mathrm{nm}]$ & Quantum yield $\Phi_{\mathrm{em}}$ \\
\hline $\mathbf{1}$ & $294(4.75), 373^{[\mathrm{a}]}(16.01), 399 \operatorname{sh}(8.04)$ & 466 & 0.11 \\
$\mathbf{2}$ & $288(3.04), 354^{[\mathrm{a}]}(12.36)$ & 460 & 0.51 \\
$\mathbf{3}$ & $288(2.68), 355^{[\mathrm{a}]}(12.09)$ & 438 & 0.46 \\
$\mathbf{4 a}$ & $340^{[\mathrm{a}]}(12.54), 374 \mathrm{sh}(1.25)$ & 411 & 0.92 \\
$\mathbf{4 b}$ & $247(1.11), 339^{[\mathrm{a}]}(11.96), 398(1.57)$ & 470 & 0.83 \\
$\mathbf{4 c}$ & $263(2.20), 336^{\mathrm{a}]}(11.69), 400(3.02)$ & 461 & 0.52 \\
$\mathbf{5}$ & $280(1.24), 366^{[\mathrm{a}]}(11.95), 392 \mathrm{sh}(5.64)$ & 480 & 0.17 \\
$\mathbf{7}$ & $275(6.28), 307(4.45), 398^{[\mathrm{a}]}(13.76), 420(9.36)$ & 475 & 0.14 \\
$\mathbf{9}$ & $305(2.93), 388^{[\mathrm{a}]}(8.55)$ & 432 & 0.34 \\
$\mathbf{1 1}$ & $268(3.83), 325 \mathrm{sh}(8.79), 361^{[\mathrm{a}]}(28.97), 384 \mathrm{sh}(19.01)$ & 0.21 \\
$\mathbf{1 2}$ & $261 \mathrm{sh}(1.92), 320 \mathrm{sh}(5.56), 356^{[\mathrm{a}]}(20.13), 378 \mathrm{sh}(12.04)$ & 429 & 0.29 \\
$\mathbf{1 3}$ & $277(13.66), 312 \mathrm{sh}(7.22), 378^{[\mathrm{a}]}(35.16), 400 \mathrm{sh}(28.42)$ & 439 & 0.09 \\
$\mathbf{1 4}$ & $372^{[\mathrm{a}]}(36.72), 395 \mathrm{sh}(25.12)$ & 436 & 0.52 \\
$\mathbf{1 6}$ & $300(20.78), 334(23.55), 407^{[\mathrm{a}]}(30.08)$ & 486 & 0.06 \\
$\mathbf{1 7}$ & $297(19.90), 333(24.36), 392^{[\mathrm{a}]}(28.62)$ & 487 & 0.05 \\
$\mathbf{1 8}$ & $344(25.90), 409^{[\mathrm{a}]}(25.00)$ & 487 & $-[\mathrm{b}]$
\end{tabular}

[a] Excitation wavelength for the emission spectra. [b] Not observed with very low quantum effciency. 
As in the case for the absorption spectra, the emission spectra of triisopropylsilyl-substituted benzene system 1-4 also display an analogous red shift as the number of arms increases. Compound $\mathbf{4 c}$ shows the emission data with red shift about 50-60 $\mathrm{nm}$ in comparison to those of $\mathbf{4 a}$ and $\mathbf{4 b}$ as a result of incorporating the electron-donating alkoxy groups. Similar to the trend of absorption spectra, the emission spectrum of $\mathbf{1 1}$ with triphenylene core is blue-shifted relative to those with benzene core. Compound 4a shows excellent fluorescence intensity with the highest quantum yield $\left(\Phi_{\mathrm{em}} \approx 0.92\right)$. Due to incorporating the two electrondonating alkoxy groups, complex $\mathbf{4 c}$ show the emission data with red shift about $60 \mathrm{~nm}$ and lower quantum yield $\left(\Phi_{\mathrm{em}}\right.$ $\approx 0.52$ ) in comparison to those of $\mathbf{4 a}$ and $\mathbf{4 b}$.

On the whole, with incorporation of metal into multiple alkynyl compounds, the emission spectra of metal complexes show a red shift relative to those of alkynyl and silyl compounds. The tendency of wavelength shifts in emission spectra is similar to that of their corresponding absorption spectra due to the same electronic factors. ${ }^{[10 b]}$ For example, after incorporation of palladium moieties, the low quantum yield for $\mathbf{1 3}$ with triphenylene as a core decreases to 0.09 relative to that for $\mathbf{5}$ with 0.29 . In addition, a red shift in the emission energies is observed for metal complexes on going from the palladium complexes to the platinum analogs; this is indicative of the involvement of the triplet metal-to-alkynyl MLCT character in emissive states. ${ }^{[10 a]}$ For the platinum complexes, the emission spectra of 16-18 show nearly the same band at $487 \mathrm{~nm}$. Accordingly, the introduction of six electron-rich $\mathrm{Cy}_{3} \mathrm{PAu}$ moieties or triisopropylsilyl groups into the platinum acetylide complex seems to have almost no influence on the emission energy. Complexes $\mathbf{1 6}$ and 17 display lower quantum efficiency $\left(\Phi_{\mathrm{em}} \approx 0.05\right)$ than that of 7 with palladium moieties $\left(\Phi_{\mathrm{em}} \approx 0.14\right)$. Moreover, when the terminal alkynyl protons of complex 17 are substituted by gold moieties to form complex 18, the quantum efficiency (ca. 0.005) is even lower. However, gold complex 14 show the highest quantum efficiency $\left(\Phi_{\mathrm{em}} \approx 0.52\right)$ in these metal acetylide complexes.

\section{Conclusions}

We use benzene and triphenylene as cores to synthesize a series of star-shaped molecules with extended $\pi$ conjugative system by Sonogashira reaction. Palladium acetylide complexes can be obtained by appropriate incorporation of the $\left(\mathrm{PR}_{3}\right)_{2} \mathrm{PdCl}$ moiety. The photophysical data of metal acetylide complexes show that introduction of electron-rich palladium or triisopropyl groups makes absorption peaks shift to longer wavelength and higher extinction coefficients relative to that of organic molecules. However, the quantum yields of palladium complexes are decreased in comparison with free organic molecules. In organic molecules, the blueemitting compounds $\mathbf{4 a}$ and $\mathbf{4 b}$ show excellent fluorescence intensity with high quantum yield $\left(\Phi_{\mathrm{em}} \mathbf{4 a}=0.92\right)$. In addition, gold acetylide complexes can also be obtained from terminal alkynyl ligands with $\left(\mathrm{Cy}_{3} \mathrm{P}\right) \mathrm{AuCl}$ in the presence of appropriate base. Heterometallic polynuclear complex $\mathbf{1 8}$ containing Pt and Au metals has also been prepared.

\section{Experimental Section}

General Procedures: All manipulations were performed under nitrogen using vacuum-line, dry box, and standard Schlenk techniques. $\mathrm{CH}_{2} \mathrm{Cl}_{2}$ was distilled from $\mathrm{CaH}_{2}$ and diethyl ether and THF from $\mathrm{Na}$ /diphenyl ketyl. All other solvents and reagents were of reagent grade and were used as received. NMR spectra were recorded with Bruker AC-300 and DMX-500 FT-NMR spectrometers at room temperature (unless states otherwise) and are reported in units of $\delta$ with residual protons in the solvents as a standard $\left(\mathrm{CDCl}_{3}, \delta=\right.$ 7.24 ppm; $\mathrm{CD}_{2} \mathrm{Cl}_{2}, \delta=5.32$; $\left[\mathrm{D}_{8}\right] \mathrm{THF}, \delta=1.73 ; 3.58$ ). FAB mass spectra were recorded with a JEOL SX-102A spectrometer. MALDI-mass spectra were collected Voyager DE-PRO (Applied Biosystem, Houston, USA) equipped with a nitrogen laser $(337 \mathrm{~nm})$ and operated in the delayed extraction reflector mode. 1-Ethynyl-4-[2-(triisopropylsilyl)ethynyl]benzene, (A) was prepared according to the literature methods ${ }^{[13]}$ as were $\mathrm{Au}\left(\mathrm{PCy}_{3}\right) \mathrm{Cl}^{[24]}$ and 2,3,6,7,10,11-hexabromotriphenylene. ${ }^{[25]}$ The complex trans-dichlorobis(triethylphosphane)palladium(II) was obtained from Aldrich Chemical Co. Absorption spectra were obtained using HP 8453 diode array spectrophotometer. Emission spectra were taken using Hitachi F-4500 luminescence spectrometer. Luminescence quantum yield $\left(\Phi_{\mathrm{em}}\right)$ were calculated relative to quinine sulfate dihydrate in $1 \mathrm{~N} \mathrm{H}_{2} \mathrm{SO}_{4}(\mathrm{aq})\left(\Phi_{\mathrm{em}}=0.52\right) \cdot{ }^{[26]}$ Elemental analyses were carried with Perkin-Elmer $2400 \mathrm{CHN}$ elemental analyzer.

Synthesis of 1,2,3,4,5-Pentabromo-6-dodecyloxybenzene (B): 2-Butanone $(20 \mathrm{~mL})$ was added to a $50-\mathrm{mL}$ Schlenk flask containing pentabromophenol (977 mg, $2 \mathrm{mmol}$ ), 1-bromododecane (700 mg, $2.8 \mathrm{mmol}$ ) and $\mathrm{K}_{2} \mathrm{CO}_{3}(553 \mathrm{mg}, 4 \mathrm{mmol})$. The mixture was heated at reflux for $24 \mathrm{~h}$. After cooling to room temperature, the solvent was removed under vacuum. The residue was extracted with EtOAc $(2 \times 40 \mathrm{~mL})$, and the solution was dried with $\mathrm{MgSO}_{4}$. After filtration, the organic solution was concentrated under reduced pressure. Column chromatography (silica gel, hexane/EtOAc, 9:1) of the residue removed excess 1-bromododecane and gave 1,2,3,4,5pentabromo-6-dodecyloxybenzene as a white powder in $60 \%$ yield $(788 \mathrm{mg})$ by the eluent with hexane/EtOAc (1:1). Spectroscopic data of B: ${ }^{1} \mathrm{H}$ NMR $\left(\mathrm{CDCl}_{3}\right): \delta=3.97\left(\mathrm{t},{ }^{3} J_{\mathrm{H}-\mathrm{H}}=6.6 \mathrm{~Hz}, 2 \mathrm{H}\right.$, $\left.\mathrm{OCH}_{2}\right), 1.90-1.80\left(\mathrm{~m}, 2 \mathrm{H}, \mathrm{CH}_{2}\right), 1.54-1.44\left(\mathrm{~m}, 18 \mathrm{H}, \mathrm{CH}_{2}\right), 0.86$ $\left(\mathrm{t},{ }^{3} J_{\mathrm{H}-\mathrm{H}}=6.6 \mathrm{~Hz}, 3 \mathrm{H}, \mathrm{CH}_{3}\right) \mathrm{ppm} .{ }^{13} \mathrm{C} \mathrm{NMR}\left(\mathrm{CDCl}_{3}\right): \delta=154.6$, 128.3, 124.4, $121.9(\mathrm{Ph}), 73.7\left(\mathrm{OCH}_{2}\right), 31.9,29.9,29.6,29.6,29.6$, 29.4, 29.3, 25.8, $22.7\left(\mathrm{CH}_{2}\right), 14.1\left(\mathrm{CH}_{3}\right)$ ppm. MS (FAB): $\mathrm{m} / \mathrm{z}=$ $652\left[\mathrm{M}^{+}, \mathrm{Br}=79.9\right] . \mathrm{C}_{18} \mathrm{H}_{20} \mathrm{Br}_{5} \mathrm{O}$ (651.87): calcd. C 33.16, H 3.09; found C 33.28, H 3.07.

Synthesis of 1,2,4,5-Tetrabromo-3,6-dibutoxybenzene (C): Synthesis of $\mathbf{C}$ followed the same procedure as that used for the preparation of $\mathbf{B}$. Their spectroscopic data are the same as that of literature. ${ }^{[27]}$

Synthesis of 1,2,4,5-Tetrabromo-3,6-dodecyloxybenzene (D): Synthesis of $\mathbf{D}$ followed the same procedure as that used for the preparation of $\mathbf{B}$, with $77 \%$ yield. Spectroscopic data of $\mathbf{D}$ : ${ }^{1} \mathrm{H}$ NMR $\left(\mathrm{CDCl}_{3}\right): \delta=3.94\left(\mathrm{t},{ }^{3} J_{\mathrm{H}-\mathrm{H}}=6.5 \mathrm{~Hz}, 4 \mathrm{H}, \mathrm{OCH}_{2}\right), 1.89-1.80(\mathrm{~m}$, $\left.4 \mathrm{H}, \mathrm{CH}_{2}\right), 1.54-1.25\left(\mathrm{~m}, 36 \mathrm{H}, \mathrm{CH}_{2}\right), 0.86\left(\mathrm{t},{ }^{3} \mathrm{~J}_{\mathrm{H}-\mathrm{H}}=6.5 \mathrm{~Hz}, 6\right.$ $\left.\mathrm{H}, \mathrm{CH}_{3}\right)$ ppm. ${ }^{13} \mathrm{C} \mathrm{NMR}\left(\mathrm{CDCl}_{3}\right): \delta=152.0(\mathrm{C}-2), 121.4(\mathrm{C} 1)$, 73.6 $\left(\mathrm{OCH}_{2}\right), 31.9,29.9,29.7,29.6,29.4,25.8,22.7\left(\mathrm{CH}_{2}\right), 14.1$ $\left(\mathrm{CH}_{3}\right)$ ppm. $\mathrm{C}_{30} \mathrm{H}_{50} \mathrm{Br}_{4} \mathrm{O}_{2}$ (762.33): calcd. C 47.27, $\mathrm{H}$ 6.61; found C 47.30, H, 6.58.

Preparation of Compound 1: Compound A (2.82 g, $10 \mathrm{mmol})$ was added to a stirred suspension of hexabromobenzene $(0.732 \mathrm{~g}$, 
$1.33 \mathrm{mmol}), \quad \mathrm{PdCl}_{2}\left(\mathrm{PPh}_{3}\right)_{2} \quad(93 \mathrm{mg}, \quad 0.13 \mathrm{mmol}), \quad \mathrm{CuI} \quad(25 \mathrm{mg}$, $0.13 \mathrm{mmol})$, and $\mathrm{PPh}_{3}(174 \mathrm{mg}, 0.67 \mathrm{mmol})$ in $\mathrm{Et}_{3} \mathrm{~N}(60 \mathrm{~mL})$ under nitrogen. The mixture was stirred at $100{ }^{\circ} \mathrm{C}$ for $48 \mathrm{~h}$. After cooling to room temperature, the solvent was removed under vacuum and the resulting residue was washed with hexanes and $\mathrm{H}_{2} \mathrm{O} / \mathrm{EtOH}(1: 2)$ to give the yellow product $(1.96 \mathrm{~g}, 84 \%$ yield). Spectroscopic data of 1: ${ }^{1} \mathrm{H}$ NMR $\left(\mathrm{CDCl}_{3}\right): \delta=7.51\left(\mathrm{~d},{ }^{3} J_{\mathrm{H}-\mathrm{H}}=8.5 \mathrm{~Hz}, 12 \mathrm{H}, \mathrm{C}_{6} \mathrm{H}_{4}\right)$, $7.47\left(\mathrm{~d},{ }^{3} J_{\mathrm{H}-\mathrm{H}}=8.5 \mathrm{~Hz}, 12 \mathrm{H}, \mathrm{C}_{6} \mathrm{H}_{4}\right), 1.13$ (m, $126 \mathrm{H}$, TIPS) ppm. ${ }^{13} \mathrm{C}$ NMR $\left(\mathrm{CDCl}_{3}\right): \delta=132.2,131.5,127.4,124.2,122.7(\mathrm{Ph})$, 106.5, 99.4, 93.6, $88.8(\mathrm{C}=\mathrm{C}), 18.7\left(\mathrm{CH}_{3}\right), 11.3(\mathrm{CH})$ ppm. MALDI-TOF-MS (DHB): $m / z=1761.23\left[\mathrm{M}^{+}+1\right]$. IR $(\mathrm{KBr}$, $\left.\mathrm{cm}^{-1}\right): \tilde{v}=2144\left(v_{\mathrm{C} \equiv \mathrm{C}}\right) . \mathrm{C}_{120} \mathrm{H}_{150} \mathrm{Si}_{6}(1760.99)$ : calcd. C 81.85, H 8.59; Found C 81.90, H 8.53.

Preparation of Compound 2: Compound A (338 mg, $1.2 \mathrm{mmol}$ ) was added to a stirred suspension of $\mathbf{B}(131 \mathrm{mg}, 0.2 \mathrm{mmol})$, $\mathrm{PdCl}_{2}\left(\mathrm{PPh}_{3}\right)_{2}(14 \mathrm{mg}, 0.02 \mathrm{mmol}), \mathrm{CuI}(3.8 \mathrm{mg}, 0.02 \mathrm{mmol})$, and $\mathrm{PPh}_{3}(14 \mathrm{mg}, 0.02 \mathrm{mmol})$ in $\mathrm{Et}_{3} \mathrm{~N}(15 \mathrm{~mL})$ under nitrogen. The mixture was stirred at $100{ }^{\circ} \mathrm{C}$ for $48 \mathrm{~h}$. After cooling to room temperature, the solvent was removed and the resulting residue was extracted with THF $(3 \times 10 \mathrm{~mL})$. The solvent was evaporated and the residue was passed through silica gel using hexanes as the eluent to remove the excess A. The crude product was eluted with EtOAc/ hexanes (1:1). The solvent was removed under vacuum and the residue washed with EtOH $(20 \mathrm{~mL})$ to give bright-yellow solid 2 . (229 mg, 69\% yield). Spectroscopic data of 2: ${ }^{1} \mathrm{H}$ NMR $\left(\mathrm{CDCl}_{3}\right)$ : $\delta=7.51-7.44(\mathrm{~m}, 20 \mathrm{H}, \mathrm{Ph}), 4.34\left(\mathrm{t},{ }^{3} J_{\mathrm{H}-\mathrm{H}}=6.3 \mathrm{~Hz}, 2 \mathrm{H}, \mathrm{OCH}_{2}\right)$, 1.94-1.84 (m, $\left.2 \mathrm{H}, \mathrm{CH}_{2}\right), 1.55-1.22\left(\mathrm{~m}, 18 \mathrm{H}, \mathrm{CH}_{2}\right), 1.12(\mathrm{~m}, 105$ $\mathrm{H}$, TIPS), $0.86\left(\mathrm{t},{ }^{3} J_{\mathrm{H}-\mathrm{H}}=6.6 \mathrm{~Hz}, 3 \mathrm{H}, \mathrm{CH}_{3}\right) \mathrm{ppm} .{ }^{13} \mathrm{C} \mathrm{NMR}$ $\left(\mathrm{CDCl}_{3}\right): \delta=160.7,132.2,132.1,131.5,131.3,128.9,124.2,124.0$, 123.9, 123.8, 123.1, 122.8, 122.7, $120.1(\mathrm{Ph}), 106.5,99.4,99.3,97.1$, 93.5, 93.4, 93.3, 88.9, 88.5, 86.1 (C=C), 75.1 $\left(\mathrm{OCH}_{2}\right), 31.9,30.6$, 29.6, 29.3, 26.3, $22.67\left(\mathrm{CH}_{2}\right), 18.7\left(\mathrm{CH}_{3}\right), 14.1\left(\mathrm{CH}_{3}\right), 11.3(\mathrm{CH})$ ppm. MALDI-TOF-MS (DHB): $m / z=1665.95\left[\mathrm{M}^{+}+1\right]$. IR $(\mathrm{KBr}$, $\left.\mathrm{cm}^{-1}\right): \tilde{v}=2144\left(v_{\mathrm{C} \equiv \mathrm{C}}\right) \cdot \mathrm{C}_{113} \mathrm{H}_{150} \mathrm{OSi}_{5}(1644.83)$ : calcd. C 81.52, H, 9.08; found $\mathrm{C} 81.70, \mathrm{H} 9.01$.

Preparation of Compound 3: Compound A (451 mg, $1.2 \mathrm{mmol})$ was added to a stirred suspension of 2,3,4,5,6-pentabromotoluene (97 mg, $0.2 \mathrm{mmol}), \mathrm{PdCl}_{2}\left(\mathrm{PPh}_{3}\right)_{2}(14 \mathrm{mg}, 0.02 \mathrm{mmol}), \mathrm{CuI}$ (3.8 mg, $0.02 \mathrm{mmol}$ ), and $\mathrm{PPh}_{3}(14 \mathrm{mg}, 0.02 \mathrm{mmol})$ in $\mathrm{Et}_{3} \mathrm{~N}(15 \mathrm{~mL})$ under nitrogen. The mixture was stirred at $100{ }^{\circ} \mathrm{C}$ for $48 \mathrm{~h}$. After cooling to room temperature, the solvent was removed under vacuum and the resulting residue was extracted with THF $(3 \times 10 \mathrm{~mL})$. The solvent was removed and the residue was passed through silica gel using hexane as the eluent to remove excess $\mathbf{A}$. The desired product was then eluted with EtOAc/hexane (1:1). The solvent was removed and the residue was washed with EtOH $(20 \mathrm{~mL})$ to give brightyellow solid 3 (188 mg, 63\% yield). Spectroscopic data of 3: ${ }^{1} \mathrm{H}$ NMR $\left(\mathrm{CDCl}_{3}\right): \delta=7.51-7.44(\mathrm{~m}, 20 \mathrm{H}, \mathrm{Ph}), 2.74\left(\mathrm{~s}, 3 \mathrm{H}, \mathrm{CH}_{3}\right)$, $1.12(\mathrm{~m}, 105 \mathrm{H}, \mathrm{TIPS}) \mathrm{ppm} .{ }^{13} \mathrm{C} \mathrm{NMR}\left(\mathrm{CDCl}_{3}\right): \delta=142.3,132.1$, $131.4,127.4,125.9,125.5,124.0,123.8,123.0,122.9,122.8(\mathrm{Ph})$, 106.6, 99.2, 98.8, 93.4, 93.2, 89.5, 88.8, $88.5(\mathrm{C}=\mathrm{C}), 20.2\left(\mathrm{CH}_{3}\right)$, $18.7\left(\mathrm{CH}_{3}\right), 11.3(\mathrm{CH})$ ppm. MALDI-TOF-MS (DHB): $\mathrm{m} / \mathrm{z}=$ $1495.0\left[\mathrm{M}^{+}\right] . \quad$ IR $\left(\mathrm{KBr}, \mathrm{cm}^{-1}\right): \tilde{v}=2144\left(v_{\mathrm{C} \equiv \mathrm{C}}\right) . \mathrm{C}_{102} \mathrm{H}_{128} \mathrm{Si}_{5}$ (1494.54): calcd. C 81.97, H 8.63; found C 81.75, H 8.53.

Preparation of Compound 4a: A mixture of tetrabromobenzene (157 mg, $0.4 \mathrm{mmol}$ ) and $\mathbf{A}(496 \mathrm{mg}, 1.76 \mathrm{mmol})$ in $30 \mathrm{~mL}$ of $\mathrm{Et}_{3} \mathrm{~N}$ was stirred in the presence of $\mathrm{PdCl}_{2}\left(\mathrm{PPh}_{3}\right)_{2}(22 \mathrm{mg}, 0.032 \mathrm{mmol})$ and $\mathrm{CuI}(6 \mathrm{mg}, 0.032 \mathrm{mmol})$ as catalyst at $100^{\circ} \mathrm{C}$ for $36 \mathrm{~h}$. After cooling to room temperature, the solvent was removed and excess A was removed by washing with $n$-hexane $(2 \times 10 \mathrm{~mL})$ and ethyl alcohol $(2 \times 10 \mathrm{~mL})$ to give the product as yellow solid $(317 \mathrm{mg}$, $66 \%$ yield). Spectroscopic data of $4 \mathbf{a}:{ }^{1} \mathrm{H}$ NMR $\left(\mathrm{CDCl}_{3}\right): \delta=7.73$ (s, $2 \mathrm{H}, \mathrm{Ph}), 7.46$ (s, $16 \mathrm{H}, \mathrm{Ph}), 1.12$ (m, $84 \mathrm{H}, \mathrm{TIPS}) \mathrm{ppm} .{ }^{13} \mathrm{C}$ NMR $\left(\mathrm{CDCl}_{3}\right): \delta=134.9,132.1,131.4,125.3,124.0,122.6(\mathrm{Ph})$, 106.5, 99.1, 93.3, $89.1(\mathrm{C}=\mathrm{C}), 18.7\left(\mathrm{CH}_{3}\right), 14.1\left(\mathrm{CH}_{3}\right), 11.3(\mathrm{CH})$ ppm. IR $\left(\mathrm{KBr}, \mathrm{cm}^{-1}\right): \tilde{v}=2144\left(v_{\mathrm{C} \equiv \mathrm{C}}\right) . \mathrm{MS}(\mathrm{MALDI}-\mathrm{TOF}): \mathrm{m} / \mathrm{z}$ $=1199.7\left[\mathrm{M}^{+}\right] . \mathrm{C}_{82} \mathrm{H}_{102} \mathrm{Si}_{4}$ (1200.03): calcd. C 82.07, H 8.57; found C 82.30, H, 8.66.

Preparation of Compound 4b: Compound A (496 mg, $1.76 \mathrm{mmol}$ ) was added to a stirred suspension of 2,3,5,6-tretabromo- $p$-xylene (169 mg, $0.4 \mathrm{mmol}), \mathrm{PdCl}_{2}\left(\mathrm{PPh}_{3}\right)_{2}(22 \mathrm{mg}, 0.032 \mathrm{mmol}), \mathrm{CuI}(6 \mathrm{mg}$, $0.032 \mathrm{mmol})$, and $\mathrm{PPh}_{3}(14 \mathrm{mg}, 0.02 \mathrm{mmol})$ in $\mathrm{Et}_{3} \mathrm{~N}(30 \mathrm{~mL})$ under nitrogen. The mixture was heated to reflux for $36 \mathrm{~h}$. After cooling to room temperature, the solvent was removed and the resulting residue was extracted with THF $(3 \times 10 \mathrm{~mL})$. The solvent was removed and the residue was passed through a silica gel column using $n$-hexane as the eluent to remove excess $\mathbf{A}$. The product $4 \mathbf{b}$ was eluted with THF/n-hexane (1:2). The solvent was removed and the residue washed with EtOH $(20 \mathrm{~mL})$ to give green-yellow solid $\mathbf{4 b}$ in $51 \%$ yield $(251 \mathrm{mg})$ Spectroscopic data of $\mathbf{4 b}$ : ${ }^{1} \mathrm{H}$ NMR $\left(\mathrm{CDCl}_{3}\right)$ : $\delta=7.47\left(\mathrm{~d},{ }^{3} J_{\mathrm{H}-\mathrm{H}}=8.6 \mathrm{~Hz}, 8 \mathrm{H}, \mathrm{Ph}\right), 7.44\left(\mathrm{~d},{ }^{3} J_{\mathrm{H}-\mathrm{H}}=8.6 \mathrm{~Hz}, 8\right.$ $\mathrm{H}, \mathrm{Ph}), 2.70\left(\mathrm{~s}, 6 \mathrm{H}, \mathrm{CH}_{3}\right), 1.12\left(\mathrm{~m}, 84 \mathrm{H}\right.$, TIPS) ppm. ${ }^{13} \mathrm{C} \mathrm{NMR}$ $\left(\mathrm{CDCl}_{3}\right): \delta=139.9,132.1,131.3,125.4,123.8,123.0(\mathrm{Ph}), 106.6$, 98.7, 93.2, $89.2(\mathrm{C}=\mathrm{C}), 19.8\left(\mathrm{CH}_{3}\right), 18.7\left(\mathrm{CH}_{3}\right), 11.3(\mathrm{CH}) \mathrm{ppm}$. IR $\left(\mathrm{KBr}, \mathrm{cm}^{-1}\right): \tilde{v}=2144\left(v_{\mathrm{C} \equiv \mathrm{C}}\right)$. MS (MALDI-TOF): $\mathrm{m} / \mathrm{z}=1227.7$ $\left[\mathrm{M}^{+}\right] . \mathrm{C}_{84} \mathrm{H}_{106} \mathrm{Si}_{4}$ (1228.08): calcd. C 82.15, H 8.07; found $\mathrm{C} 82.33$, H 8.15 .

Preparation of Compound 4c: Compound A (271 mg, $0.2 \mathrm{mmol})$ was added to a stirred suspension of 1,2,4,5-tetrabomo-3,6-dibutoxybenzene $(108 \mathrm{mg}, \quad 0.2 \mathrm{mmol}), \quad \mathrm{PdCl}_{2}\left(\mathrm{PPh}_{3}\right)_{2} \quad(11 \mathrm{mg}$, $0.016 \mathrm{mmol})$, CuI (3 mg, $0.016 \mathrm{mmol})$, and $\mathrm{PPh}_{3} \quad(21 \mathrm{mg}$, $0.08 \mathrm{mmol})$ in $\mathrm{THF} / \mathrm{NEt}_{3}(30 \mathrm{~mL}, 1: 1)$ under nitrogen. The mixture was stirred at $100^{\circ} \mathrm{C}$ for $36 \mathrm{~h}$. After cooling to room temperature, the solvent was removed and the resulting residue was extracted with $n$-hexane $(3 \times 20 \mathrm{~mL})$. The solvent was removed and the residue was passed through a silica gel packed column using $n$-hexane as the eluent to remove excess A. Elution with $\mathrm{THF} / n$-hexane gave yellow solid compound $\mathbf{4 c}$ (180 mg, 67\% yield). Spectroscopic data of $4 \mathbf{c}:{ }^{1} \mathrm{H} \mathrm{NMR}\left(\mathrm{CDCl}_{3}\right): \delta=7.47(\mathrm{~s}, 16 \mathrm{H}, \mathrm{Ph}), 4.27\left(\mathrm{t},{ }^{3} J_{\mathrm{H}-\mathrm{H}}=\right.$ $\left.6.6 \mathrm{~Hz}, 4 \mathrm{H}, \mathrm{OCH}_{2}\right), 1.92-1.83\left(\mathrm{~m}, 4 \mathrm{H}, \mathrm{CH}_{2}\right), 1.68-1.56(\mathrm{~m}, 4 \mathrm{H}$, $\left.\mathrm{CH}_{2}\right), 1.12\left(\mathrm{~m}, 84 \mathrm{H}\right.$, TIPS), $0.86\left(\mathrm{t}, J=6.3 \mathrm{~Hz}, 3 \mathrm{H}, \mathrm{CH}_{3}\right) \mathrm{ppm}$. ${ }^{13} \mathrm{C} \mathrm{NMR}\left(\mathrm{CDCl}_{3}\right): \delta=157.4,132.1,131.3,123.9,122.9,121.1$ $(\mathrm{Ph}), 106.5,99.1,93.3,86.3(\mathrm{C}=\mathrm{C}), 74.6\left(\mathrm{OCH}_{2}\right), 32.5,19.5\left(\mathrm{CH}_{2}\right)$, $18.7\left(\mathrm{CH}_{3}\right), 14.0\left(\mathrm{CH}_{3}\right), 11.3(\mathrm{CH}) \mathrm{ppm}$. IR $\left(\mathrm{KBr}, \mathrm{cm}^{-1}\right): \tilde{v}=2144$ $\left(v_{\mathrm{C} \equiv \mathrm{C}}\right)$. MS (MALDI-TOF): $m / z=1343.9\left[\mathrm{M}^{+}\right] . \mathrm{C}_{90} \mathrm{H}_{118} \mathrm{O}_{2} \mathrm{Si}_{4}$ (1344.24): calcd. C 80.41, H 8.85; found C 80.73, H 8.91.

Preparation of Compound 4d: Synthesis of 4d followed the same procedure as that used for the preparation of $\mathbf{4 c}$, with $72 \%$ yield. Spectroscopic data of $\mathbf{4 d}:{ }^{1} \mathrm{H}$ NMR $\left(\mathrm{CDCl}_{3}\right): \delta=7.45(\mathrm{~s}, 16 \mathrm{H}$, $\mathrm{Ph}), 4.25\left(\mathrm{t},{ }^{3} J_{\mathrm{H}-\mathrm{H}}=6.3 \mathrm{~Hz}, 4 \mathrm{H}\right), 1.93-1.83\left(\mathrm{~m}, 4 \mathrm{H}, \mathrm{CH}_{2}\right), 1.61-$ $1.21\left(\mathrm{~m}, 18 \mathrm{H}, \mathrm{CH}_{2}\right), 1.12(\mathrm{~m}, 84 \mathrm{H}, \mathrm{TIPS}), 0.86\left(\mathrm{t},{ }^{3} \mathrm{~J}_{\mathrm{H}-\mathrm{H}}=6.6 \mathrm{~Hz}\right.$, $\left.6 \mathrm{H}, \mathrm{CH}_{3}\right) \mathrm{ppm} .{ }^{13} \mathrm{C} \mathrm{NMR}\left(\mathrm{CDCl}_{3}\right): \delta=157.4,132.1,131.3,123.9$, 122.9, 121.1 (Ph), 106.5, 99.1, 93.3, 86.3 (C=C), 75.0 $\left(\mathrm{OCH}_{2}\right), 31.9$, 30.5, 29.6, 29.3, 26.4, 22.7( $\left.\mathrm{CH}_{2}\right), 18.7\left(\mathrm{CH}_{3}\right), 14.1\left(\mathrm{CH}_{3}\right), 11.3(\mathrm{CH})$ ppm. MS (MALDI-TOF): $m / z=1568.8\left[\mathrm{M}^{+}\right] . \mathrm{C}_{106} \mathrm{H}_{150} \mathrm{O}_{2} \mathrm{Si}_{4}$ (1568.67): calcd. C 81.16, H, 9.64; found C 81.34 H 9.74.

Preparation of Compound 5: A mixture of 1 (1.96 g, $1.11 \mathrm{mmol})$ in THF $(20 \mathrm{~mL})$ and $n \mathrm{Bu}_{4} \mathrm{NF}(1 \mathrm{M}$ THF solution, $13.32 \mathrm{~mL})$ was stirred at $45^{\circ} \mathrm{C}$ overnight. The solvent was removed and EtOH $(50 \mathrm{~mL})$ was added to give yellow solid which was filtered and dried under vacuum to give 5 ( $907 \mathrm{mg}, 99 \%$ yield). Spectroscopic data of 5: ${ }^{1} \mathrm{H}$ NMR ([D $]$ THF): $\delta=7.62\left(\mathrm{~d},{ }^{3} J_{\mathrm{H}-\mathrm{H}}=8.3 \mathrm{~Hz}, 12 \mathrm{H}\right.$, $\left.\mathrm{C}_{6} \mathrm{H}_{4}\right), 7.52\left(\mathrm{~d},{ }^{3} \mathrm{~J}_{\mathrm{H}-\mathrm{H}}=8.3 \mathrm{~Hz}, 12 \mathrm{H}, \mathrm{C}_{6} \mathrm{H}_{4}\right), 3.77(\mathrm{~s}, 6 \mathrm{H}, \mathrm{C}=\mathrm{CH})$ ppm. ${ }^{13} \mathrm{C}$ NMR ([D $]$ THF): $\delta=133.3,132.8,128.6,124.7,124.0$ 
(Ph), 100.5, 89.4, 83.9, $81.7(\mathrm{C}=\mathrm{C}) \mathrm{ppm}$. IR $\left(\mathrm{KBr}, \mathrm{cm}^{-1}\right): \tilde{v}=3286$ $\left(v_{\mathrm{H}-\mathrm{C} \equiv}\right), 2195\left(v_{\mathrm{C} \equiv \mathrm{C}}\right)$. Mass $(\mathrm{FAB}): \mathrm{m} / z=823\left[\mathrm{M}^{+}+1\right]$. HRMS cacld for $\mathrm{C}_{66} \mathrm{H}_{30}$ : 822.2347; found 822.2352. $\mathrm{C}_{66} \mathrm{H}_{30}$ (822.94): $\mathrm{C}$ 96.33, H 3.67; found C 96.37, H 3.66.

Preparation of Compound 6a: A mixture of $4 a$ (340 mg, $0.28 \mathrm{mmol}$ ) and $n \mathrm{Bu}_{4} \mathrm{NF}(1.13 \mathrm{~mL}, 1 \mathrm{M}$ in THF) in THF $(10 \mathrm{~mL})$ was stirred at room temperature for $1 \mathrm{~h}$. The solvent was removed and EtOH $(20 \mathrm{~mL})$ was added to give yellow solid which was filtered and dried under vacuum to give $\mathbf{6 a}$ (160 mg, 99\% yield). Spectroscopic data of 6a: ${ }^{1} \mathrm{H}$ NMR ([D $\left.\left.{ }_{8}\right] \mathrm{THF}\right): \delta=7.82(\mathrm{~s}, 2 \mathrm{H}, \mathrm{Ph}), 7.56\left(\mathrm{~d},{ }^{3} J_{\mathrm{H}-\mathrm{H}}=\right.$ $\left.8.1 \mathrm{~Hz}, 8 \mathrm{H}, \mathrm{C}_{6} \mathrm{H}_{4}\right), 7.50\left(\mathrm{~d},{ }^{3} J_{\mathrm{H}-\mathrm{H}}=8.1 \mathrm{~Hz}, 8 \mathrm{H}, \mathrm{C}_{6} \mathrm{H}_{4}\right), 3.72(\mathrm{~s}$, $4 \mathrm{H}, \mathrm{C} \equiv \mathrm{CH}) \mathrm{ppm} .{ }^{13} \mathrm{C} \mathrm{NMR}\left(\left[\mathrm{D}_{8}\right] \mathrm{THF}\right): \delta=136.1,133.2,132.6$, 126.5, 124.4, $124.0(\mathrm{Ph}), 96.2,89.9,83.9,81.4(\mathrm{C} \equiv \mathrm{C}) \mathrm{ppm}$. IR $\left(\mathrm{KBr}, \mathrm{cm}^{-1}\right): \tilde{v}=3286\left(v_{\mathrm{H}-\mathrm{C} \equiv}\right), 2195\left(v_{\mathrm{C} \equiv \mathrm{C}}\right)$. Mass $(\mathrm{FAB}): \mathrm{m} / \mathrm{z}=$ $574.2\left[\mathrm{M}^{+}\right]$. HRMS cacld for $\mathrm{C}_{46} \mathrm{H}_{22}$ : 574.1722; found 574.1719. $\mathrm{C}_{46} \mathrm{H}_{22}$ (574.67): calcd. C 96.14, H 3.86; found C 96.21, H 3.86.

Preparation of Compound 6c: A mixture of $\mathbf{6 c}(269 \mathrm{mg}, 0.2 \mathrm{mmol})$ and $n \mathrm{Bu}_{4} \mathrm{NF}(0.8 \mathrm{~mL}, 1 \mathrm{M}$ in THF $)$ in THF $(10 \mathrm{~mL})$ was stirred at room temperature for $1 \mathrm{~h}$. The solvent was removed and EtOH $(20 \mathrm{~mL})$ was added to give yellow solid and dried under vacuum (141 mg, 98\% yield). Spectroscopic data of $6 \mathbf{c}:{ }^{1} \mathrm{H} \mathrm{NMR}\left(\mathrm{CDCl}_{3}\right)$ : $\delta=7.62\left(\mathrm{~d},{ }^{3} J_{\mathrm{H}-\mathrm{H}}=8.5 \mathrm{~Hz}, 12 \mathrm{H}, \mathrm{C}_{6} \mathrm{H}_{4}\right), 7.52\left(\mathrm{~d},{ }^{3} J_{\mathrm{H}-\mathrm{H}}=8.5 \mathrm{~Hz}\right.$, $\left.12 \mathrm{H}, \mathrm{C}_{6} \mathrm{H}_{4}\right), 4.27\left(\mathrm{t},{ }^{3} J_{\mathrm{H}-\mathrm{H}}=6.3 \mathrm{~Hz}, 4 \mathrm{H}, \mathrm{OCH}_{2}\right), 3.19(\mathrm{~s}, 4 \mathrm{H}$, $\mathrm{C}=\mathrm{CH}), 1.89-1.83\left(\mathrm{~m}, 4 \mathrm{H}, \mathrm{CH}_{2}\right), 1.64-1.54\left(\mathrm{~m}, 4 \mathrm{H}, \mathrm{CH}_{2}\right), 0.95$ $\left(\mathrm{t},{ }^{3} J_{\mathrm{H}-\mathrm{H}}=6.6 \mathrm{~Hz}, 6 \mathrm{H}, \mathrm{CH}_{3}\right) \mathrm{ppm} .{ }^{13} \mathrm{C} \mathrm{NMR}\left(\mathrm{CDCl}_{3}\right): \delta=157.4$, $132.2,131.4,123.5,122.5,121.1(\mathrm{Ph}), 98.8,86.4,83.1,79.3(\mathrm{C}=\mathrm{C})$, $74.7\left(\mathrm{OCH}_{2}\right), 32.5,19.5\left(\mathrm{CH}_{2}\right), 14.0\left(\mathrm{CH}_{3}\right) \mathrm{ppm}$. IR $\left(\mathrm{KBr}, \mathrm{cm}^{-1}\right): \tilde{v}$ $=3276\left(v_{\mathrm{H}-\mathrm{C} \equiv}\right), 2195\left(v_{\mathrm{C} \equiv \mathrm{C}}\right)$. Mass (FAB): $m / z=718\left[\mathrm{M}^{+}\right]$. HRMS calcd. for $\mathrm{C}_{54} \mathrm{H}_{38} \mathrm{O}_{2}$ : 718.2872; found 718.2877. $\mathrm{C}_{54} \mathrm{H}_{38} \mathrm{O}_{2}$ (718.88): calcd. C 90.22, H 5.33; found C 90.37, H 5.44.

Preparation of Compound 7a: trans $-\mathrm{Pd}\left(\mathrm{PBu}_{3}\right)_{2} \mathrm{Cl}_{2} \quad(174 \mathrm{mg}$, $0.3 \mathrm{mmol})$ was dissolved in $\mathrm{HNEt}_{2}(10 \mathrm{~mL})$ containing $\mathrm{CuI}(2 \mathrm{mg})$. Compound 5 (41 mg, $0.05 \mathrm{mmol})$ in THF $(10 \mathrm{~mL})$ was added and the reaction mixture stirred for $8 \mathrm{~h}$ at room temperature under nitrogen. The solvent was then removed under reduced pressure. The residue was extracted with diethyl ether/ $n$-hexane (1:1) and the solution was dried with anhydrous $\mathrm{MgSO}_{4}$ followed by filtration with celite. The filtrate was then concentrated under reduced pressure and passed through a short column of basic aluminum oxide using petroleum ether (boiling range $40-65^{\circ} \mathrm{C}$ ) as the eluent to remove excess trans- $\mathrm{Pd}\left(\mathrm{PBu}_{3}\right)_{2} \mathrm{Cl}_{2}$. The hexanuclear complex 7a was eluted with EtOAc and the solvent was removed by rotary evaporator to give pale yellow solid 7a (162 mg, 79\% yield). Spectroscopic data of 7a: ${ }^{31} \mathrm{P}$ NMR $\left(\mathrm{CDCl}_{3}\right): \delta=10.80 .{ }^{1} \mathrm{H}$ NMR $\left(\mathrm{CDCl}_{3}\right): \delta=7.48\left(\mathrm{~d},{ }^{3} J_{\mathrm{H}-\mathrm{H}}=8.2 \mathrm{~Hz}, 2 \mathrm{H}, \mathrm{Ph}\right), 7.21\left(\mathrm{~d},{ }^{3} J_{\mathrm{H}-\mathrm{H}}=\right.$ $8.2 \mathrm{~Hz}, 2 \mathrm{H}, \mathrm{Ph}), 1.94-1.88\left(\mathrm{~m}, 6 \mathrm{H}, \mathrm{CH}_{2}\right), 1.57-1.37(\mathrm{~m}, 12 \mathrm{H}$, $\left.\mathrm{CH}_{2}\right), 0.91\left(\mathrm{t},{ }^{3} J_{\mathrm{H}-\mathrm{H}}=7.2 \mathrm{~Hz}, 9 \mathrm{H}, \mathrm{CH}_{3}\right) \mathrm{ppm} .{ }^{13} \mathrm{C} \mathrm{NMR}\left(\mathrm{CDCl}_{3}\right)$ : $\delta=131.5,130.6,128.7,127.1,119.9(\mathrm{Ph}), 106.3\left(\mathrm{t},{ }^{3} J_{\mathrm{C}-\mathrm{P}}=5.3 \mathrm{~Hz}\right.$, $\mathrm{C} \beta), 101.6\left(\mathrm{t},{ }^{2} J_{\mathrm{C}-\mathrm{P}}=15.6 \mathrm{~Hz}, \mathrm{C} \alpha\right), 99.6,88.3(\mathrm{C} \equiv \mathrm{C}), 26.4\left(\mathrm{CH}_{2}\right)$, $24.4\left(\mathrm{t},{ }^{2} J_{\mathrm{C}-\mathrm{P}}=6.6 \mathrm{~Hz}, \mathrm{CH}_{2}\right), 22.9\left(\mathrm{t}, J_{\mathrm{C}-\mathrm{P}}=13.6 \mathrm{~Hz}, \mathrm{CH}_{2}\right), 13.8$ $\left(\mathrm{CH}_{3}\right)$ ppm. IR $\left(\mathrm{KBr}, \mathrm{cm}^{-1}\right): \tilde{v}=2195$ and $2103\left(v_{\mathrm{C} \equiv \mathrm{C}}\right)$. $\mathrm{C}_{210} \mathrm{H}_{348} \mathrm{Cl}_{6} \mathrm{P}_{12} \mathrm{Pd}_{6}$ (4095.93): calcd. C 90.22, H 5.33; found $\mathrm{C}$ 90.37, H 5.44.

Preparation of Compound 7b: Synthesis of $\mathbf{7 b}$ followed the same procedure as that used for the preparation of $7 \mathbf{a}$ in $73 \%$ yield. Spectroscopic data of $7 \mathbf{b}:{ }^{31} \mathrm{P}$ NMR $\left(\mathrm{CD}_{2} \mathrm{Cl}_{2}\right): \delta=18.95 .{ }^{1} \mathrm{H} \mathrm{NMR}$ $\left(\mathrm{CD}_{2} \mathrm{Cl}_{2}\right): \delta=7.51\left(\mathrm{~d},{ }^{3} J_{\mathrm{H}-\mathrm{H}}=8.2 \mathrm{~Hz}, 12 \mathrm{H}, \mathrm{C}_{6} \mathrm{H}_{4}\right), 7.27(\mathrm{~d}$, $\left.{ }^{3} J_{\mathrm{H}-\mathrm{H}}=8.2 \mathrm{~Hz}, 12 \mathrm{H}, \mathrm{C}_{6} \mathrm{H}_{4}\right), 2.02-1.93\left(\mathrm{~m}, 72 \mathrm{H}, \mathrm{CH}_{2}\right), 1.26-1.16$ (m, $\left.108 \mathrm{H}, \mathrm{CH}_{3}\right)$ ppm. ${ }^{13} \mathrm{C}$ NMR $\left(\mathrm{CD}_{2} \mathrm{Cl}_{2}\right): \delta=132.10,131.40$, 129.46, 127.62, $120.20(\mathrm{Ph}), 107.24\left(\mathrm{t},{ }^{3} J_{\mathrm{C}-\mathrm{P}}=5.6 \mathrm{~Hz}, \mathrm{C} \beta\right), 101.72$ $\left(\mathrm{t},{ }^{2} J_{\mathrm{P}-\mathrm{C}}=15.8 \mathrm{~Hz}, \mathrm{C} \alpha\right), 100.39,88.62(\mathrm{C} \equiv \mathrm{C}), 16.00\left(\mathrm{t}, J_{\mathrm{C}-\mathrm{P}}=\right.$ $\left.14.0 \mathrm{~Hz}, \mathrm{CH}_{2}\right), 8.70\left(\mathrm{CH}_{3}\right)$ ppm. IR $\left(\mathrm{KBr}, \mathrm{cm}^{-1}\right): \tilde{v}=2195,2103$
$\left(v_{\mathrm{C} \equiv \mathrm{C}}\right) \cdot \mathrm{C}_{138} \mathrm{H}_{204} \mathrm{Cl}_{6} \mathrm{P}_{12} \mathrm{Pd}_{6}$ (3086.02): calcd. C 53.71, H 6.66; found C 53.90, H 6.61.

Preparation of Complex 8a: A mixture of trans- $\mathrm{Pd}\left(\mathrm{PEt}_{3}\right)_{2} \mathrm{Cl}_{2}$ (125 mg, $0.30 \mathrm{mmol}), 6 \mathbf{6 a}(43 \mathrm{mg}, 0.075 \mathrm{mmol})$ and $\mathrm{CuCl}(2 \mathrm{mg})$ was dissolved in THF $(10 \mathrm{~mL})$ then $\mathrm{Et}_{2} \mathrm{NH}(5 \mathrm{~mL})$ was added. The reaction mixture stirred overnight at room temperature under nitrogen. The solvent was then removed under reduced pressure. After the residue was extracted with $n$-hexane, the solvent was then concentrated under reduced pressure. The residues was passed through a short column of basic aluminum oxide using $\mathrm{CH}_{2} \mathrm{Cl}_{2} /$ petroleum ether (boiling range $40-65^{\circ} \mathrm{C}$ ), $1: 1$, as the eluent to remove excess trans- $\mathrm{Pd}\left(\mathrm{PEt}_{3}\right)_{2} \mathrm{Cl}_{2}$. The tetranuclear complex 8a was eluted with THF and the solvent was removed by a rotary evaporator to give complex 8a as a yellow solid (136 mg, 87\% yield). Spectroscopic data of 8a: ${ }^{31} \mathrm{P}$ NMR $\left(\mathrm{CDCl}_{3}\right): \delta=18.86 \mathrm{ppm} .{ }^{1} \mathrm{H} \mathrm{NMR}\left(\mathrm{CDCl}_{3}\right)$ : $\delta=7.70(\mathrm{~s}, 2 \mathrm{H}, \mathrm{Ph}), 7.40\left(\mathrm{~d},{ }^{3} J_{\mathrm{H}-\mathrm{H}}=8.4 \mathrm{~Hz}, 8 \mathrm{H}, \mathrm{C}_{6} \mathrm{H}_{4}\right), 7.21(\mathrm{~d}$, $\left.{ }^{3} J_{\mathrm{H}-\mathrm{H}}=8.4 \mathrm{~Hz}, 8 \mathrm{H}, \mathrm{C}_{6} \mathrm{H}_{4}\right), 2.01-1.92\left(\mathrm{~m}, 48 \mathrm{H}, \mathrm{CH}_{2}\right), 1.25-1.13$ $\left(\mathrm{m}, 72 \mathrm{H}, \mathrm{CH}_{3}\right) \mathrm{ppm} .{ }^{13} \mathrm{C} \mathrm{NMR}\left(\mathrm{CDCl}_{3}\right): \delta=134.8,131.5,130.7$, 128.3, 125.1, $119.8(\mathrm{Ph}), 106.8\left(\mathrm{t},{ }^{3} J_{\mathrm{C}-\mathrm{P}}=5.6 \mathrm{~Hz}, \mathrm{C}_{\beta}\right), 99.8(\mathrm{t}$, $\left.{ }^{2} J_{\mathrm{C}-\mathrm{P}}=15.8 \mathrm{~Hz}, \mathrm{C} \alpha\right), 95.8,88.4(\mathrm{C} \equiv \mathrm{C}), 15.5\left(\mathrm{t}, J_{\mathrm{C}-\mathrm{P}}=14.0 \mathrm{~Hz}\right.$, $\left.\mathrm{CH}_{2}\right), 8.3\left(\mathrm{CH}_{3}\right)$ ppm. Mass (FAB): $m / z=2081\left[\mathrm{M}^{+}, \mathrm{Cl}=35\right]$. $\mathrm{C}_{94} \mathrm{H}_{138} \mathrm{Cl}_{4} \mathrm{P}_{8} \mathrm{Pd}_{4}$ (2083.38): calcd. C 54.19, H 6.68; found C 54.00, H 6.73 .

Preparation of Complex 8c: $\mathrm{Et}_{2} \mathrm{NH}(5 \mathrm{~mL})$ was added to a mixture of trans-Pd( $\left.\mathrm{PEt}_{3}\right)_{2} \mathrm{Cl}_{2}$ (83 mg, $\left.0.100 \mathrm{mmol}\right), \mathbf{6 c}(36 \mathrm{mg}, 0.025 \mathrm{mmol})$ and $\mathrm{CuCl}(1 \mathrm{mg})$ dissolved in THF $(5 \mathrm{~mL})$. The reaction mixture was stirred overnight at room temperature under nitrogen. The solvent was then removed under reduced pressure. The residue was passed through a short column of basic aluminum oxide using $\mathrm{CH}_{2} \mathrm{Cl}_{2}$ /petroleum ether (boiling range $40-65^{\circ} \mathrm{C}$ ), $1: 1$, as the eluent to remove excess trans- $\mathrm{Pd}\left(\mathrm{PEt}_{3}\right)_{2} \mathrm{Cl}_{2}$. The tetranuclear complex $8 \mathrm{c}$ was eluted with THF and the solvent was removed by rotary evaporator to give complex $\mathbf{8 c}$ as orange solid. (35 mg, $62 \%$ yield). Spectroscopic data of $8 \mathrm{c}:{ }^{31} \mathrm{P}$ NMR $\left(\mathrm{CDCl}_{3}\right): \delta=18.86 \mathrm{ppm} .{ }^{1} \mathrm{H}$ NMR $\left(\mathrm{CDCl}_{3}\right): \delta=7.41\left(\mathrm{~d}, J=8.2 \mathrm{~Hz}, 8 \mathrm{H}, \mathrm{C}_{6} \mathrm{H}_{4}\right), 7.21\left(\mathrm{~d},{ }^{3} J_{\mathrm{H}-\mathrm{H}}=\right.$ $\left.8.2 \mathrm{~Hz}, 8 \mathrm{H}, \mathrm{C}_{6} \mathrm{H}_{4}\right), 4.24\left(\mathrm{t},{ }^{3} J_{\mathrm{H}-\mathrm{H}}=6.3 \mathrm{~Hz}, 4 \mathrm{H}, \mathrm{OCH}_{2}\right), 2.01-$ $1.91\left(\mathrm{~m}, 48 \mathrm{H}, \mathrm{CH}_{2}\right), 1.88-1.83\left(\mathrm{~m}, 4 \mathrm{H}, \mathrm{CH}_{2}\right), 1.64-1.57(\mathrm{~m}, 4 \mathrm{H}$, $\left.\mathrm{CH}_{2}\right), 1.25-1.13\left(\mathrm{~m}, 72 \mathrm{H}, \mathrm{CH}_{2}\right), 0.95\left(\mathrm{t}, J=6.6 \mathrm{~Hz}, 6 \mathrm{H}, \mathrm{CH}_{3}\right)$ ppm. ${ }^{13} \mathrm{C} \mathrm{NMR}\left(\mathrm{CDCl}_{3}\right): \delta=157.2\left(\mathrm{O}-\mathrm{C}, \mathrm{C}_{6} \mathrm{H}_{4}\right), 131.3,130.7$, $128.2,120.8,120.1(\mathrm{Ph}), 106.7\left(\mathrm{t},{ }^{3} J_{\mathrm{C}-\mathrm{P}}=5.6 \mathrm{~Hz}, \mathrm{C} \beta\right), 99.7(\mathrm{t}$, $\left.{ }^{2} J_{\mathrm{C}-\mathrm{P}}=14.3 \mathrm{~Hz}, \mathrm{C} \alpha\right), 99.8,85.8(\mathrm{C} \equiv \mathrm{C}), 74.4\left(\mathrm{OCH}_{2}\right), 32.5,19.5$ $\left(\mathrm{CH}_{2}\right), 15.4\left(\mathrm{t}, J_{\mathrm{C}-\mathrm{P}}=14.0 \mathrm{~Hz}, \mathrm{CH}_{2}\right), 14.0\left(\mathrm{CH}_{3}\right), 8.4\left(\mathrm{~s}, \mathrm{CH}_{3}\right) \mathrm{ppm}$. IR $\left(\mathrm{KBr}, \mathrm{cm}^{-1}\right): \tilde{v}=2195,2103\left(v_{\mathrm{C} \equiv \mathrm{C}}\right)$. Mass (FAB): $\mathrm{m} / \mathrm{z}=2227$ $\left[\mathrm{M}^{+}, \mathrm{Cl}=35.45\right] . \mathrm{C}_{102} \mathrm{H}_{154} \mathrm{Cl}_{4} \mathrm{O}_{2} \mathrm{P}_{8} \mathrm{Pd}_{4}$ (2227.59): calcd. C 55.00, $\mathrm{H}$ 6.97; found C 55.31, H 6.79 .

Preparation of Complex 9a: A mixture of 5 (41 $\mathrm{mg}, 0.05 \mathrm{mmol})$, $\mathrm{NaOH}$ (36 mg, $0.9 \mathrm{mmol})$ dissolved in EtOH $(2 \mathrm{~mL})$ and $\mathrm{Au}\left(\mathrm{PCy}_{3}\right) \mathrm{Cl}(154 \mathrm{mg}, 0.3 \mathrm{mmol})$ dissolved in THF $(10 \mathrm{~mL})$ was stirred at room temperature under nitrogen for $3 \mathrm{~h}$. The solvent was then removed, and the residue was washed with $\mathrm{EtOH} / \mathrm{H}_{2} \mathrm{O}$ $(1: 1,10 \mathrm{~mL})$ and acetone to give the yellow solid 9a $(153 \mathrm{mg}, 83 \%$ yield). Spectroscopic data of 9a: ${ }^{31} \mathrm{P} \mathrm{NMR}\left(\mathrm{CDCl}_{3}\right): \delta=56.81 \mathrm{ppm}$. ${ }^{1} \mathrm{H} \mathrm{NMR}\left(\mathrm{CDCl}_{3}\right): \delta=7.47\left(\mathrm{~d},{ }^{3} J_{\mathrm{H}-\mathrm{H}}=8.7 \mathrm{~Hz}, 12 \mathrm{H}, \mathrm{C}_{6} \mathrm{H}_{4}\right), 7.43$ $\left(\mathrm{d},{ }^{3} J_{\mathrm{H}-\mathrm{H}}=8.7 \mathrm{~Hz}, 12 \mathrm{H}, \mathrm{C}_{6} \mathrm{H}_{4}\right), 2.01-1.24\left(\mathrm{~m}, 180 \mathrm{H}, \mathrm{PC} y_{3}\right) \mathrm{ppm}$. ${ }^{13} \mathrm{C}$ NMR $\left(\mathrm{CDCl}_{3}\right): \delta=139.9\left(\mathrm{~d},{ }^{2} J_{\mathrm{P}-\mathrm{C}}=131.2 \mathrm{~Hz}, \mathrm{C}_{\alpha}(\mathrm{Au} C \equiv \mathrm{C})\right)$, 132.3, 131.4, 127.2, 125.9, $121.0(\mathrm{Ph}), 103.5\left(\mathrm{~d},{ }^{3} J_{\mathrm{P}-\mathrm{C}}=24.5 \mathrm{~Hz}\right.$, $\left.\mathrm{C}_{\beta},(\mathrm{AuC} \equiv C)\right), 99.7,88.6,(\mathrm{C} \equiv \mathrm{C}), 33.2\left(\mathrm{~d}, J_{\mathrm{P}-\mathrm{C}}=24.5 \mathrm{~Hz}, C y_{3} \mathrm{P}\right)$, $30.7\left(\mathrm{~s}, \mathrm{Cy}_{3} \mathrm{P}\right), 27.7\left(\mathrm{~d},{ }^{2} J_{\mathrm{P}-\mathrm{C}}=11.8 \mathrm{~Hz}, \mathrm{Cy}_{3} \mathrm{P}\right), 25.9\left(\mathrm{~s}, C y_{3} \mathrm{P}\right) \mathrm{ppm}$. IR $\left(\mathrm{KBr}, \mathrm{cm}^{-1}\right): \tilde{v}=2195,2103\left(v_{\mathrm{C} \equiv \mathrm{C}}\right) . \mathrm{C}_{174} \mathrm{H}_{222} \mathrm{Au}_{6} \mathrm{P}_{6}(3681.27)$ : calcd. C 56.77, H 6.08; found C 56.91, H 6.21.

Preparation of Complex 10c: A mixture of $6 \mathrm{c}(36 \mathrm{mg}, 0.05 \mathrm{mmol})$, $\mathrm{NaOH}(8 \mathrm{mg}, 2 \mathrm{mmol})$ dissolved in $\mathrm{EtOH}(1.2 \mathrm{~mL})$ and $\mathrm{Au}-$ 
$\left(\mathrm{PCy}_{3}\right) \mathrm{Cl}(103 \mathrm{mg}, 0.2 \mathrm{mmol})$ dissolved in THF $(10 \mathrm{~mL})$ was stirred at room temperature under nitrogen for $5 \mathrm{~h}$. The solvent was removed under vacuum then the residue was washed with $\mathrm{EtOH} / \mathrm{H}_{2} \mathrm{O}$ $(1: 1,10 \mathrm{~mL})$ to give a yellow solid identified as 10c $(106 \mathrm{mg}, 81 \%$ yield). Spectroscopic data of 10c: ${ }^{31} \mathrm{P}$ NMR $\left(\mathrm{CDCl}_{3}\right): \delta=56.88$. ${ }^{1} \mathrm{H} \mathrm{NMR}\left(\mathrm{CDCl}_{3}\right): \delta=7.41\left(\mathrm{~d},{ }^{3} J_{\mathrm{H}-\mathrm{H}}=8.4 \mathrm{~Hz}, 8 \mathrm{H}, \mathrm{C}_{6} \mathrm{H}_{4}\right), 7.21$ $\left(\mathrm{d},{ }^{3} J_{\mathrm{H}-\mathrm{H}}=8.4 \mathrm{~Hz}, 8 \mathrm{H}, \mathrm{C}_{6} \mathrm{H}_{4}\right), 4.22\left(\mathrm{t},{ }^{3} J_{\mathrm{H}-\mathrm{H}}=6.3 \mathrm{~Hz}, 4 \mathrm{H}\right.$, $\left.\mathrm{OCH}_{2}\right), 2.05-1.19\left(\mathrm{~m}, 128 \mathrm{H}, \mathrm{CH}_{2}, \mathrm{Cy}_{3} \mathrm{P}\right), 0.91\left(\mathrm{t},{ }^{3} \mathrm{~J}_{\mathrm{H}-\mathrm{H}}=6.6 \mathrm{~Hz}\right.$, $\left.6 \mathrm{H}, \mathrm{CH}_{3}\right) \mathrm{ppm} .{ }^{13} \mathrm{C} \mathrm{NMR}\left(\mathrm{CDCl}_{3}\right): \delta=157.2(\mathrm{Ph}), 139.8(\mathrm{~d}$, $\left.{ }^{2} J_{\mathrm{C}-\mathrm{P}}=131.3 \mathrm{~Hz}, \mathrm{Au} C \equiv \mathrm{C}\right), 132.3,131.2,125.7,121.2,120.9(\mathrm{Ph})$, $103.3\left(\mathrm{~d},{ }^{2} J_{\mathrm{C}-\mathrm{P}}=23.8 \mathrm{~Hz}, \mathrm{AuC} \equiv \mathrm{C}\right), 99.5,85.8(\mathrm{C} \equiv \mathrm{C}), 74.4$ $\left(\mathrm{OCH}_{2}\right), 33.2\left(\mathrm{~d},{ }^{2} J_{\mathrm{C}-\mathrm{P}}=27.8 \mathrm{~Hz}, \mathrm{Cy}\right), 32.5\left(\mathrm{CH}_{2}\right), 27.1\left(\mathrm{~d},{ }^{2} J_{\mathrm{C}-\mathrm{P}}\right.$ $=11.7 \mathrm{~Hz}, \mathrm{Cy}), 25.9(\mathrm{~s}, \mathrm{Cy}), 19.5\left(\mathrm{CH}_{2}\right), 13.9\left(\mathrm{CH}_{3}\right) \mathrm{ppm}$. Mass (FAB): $m / z=2624.1\left[\mathrm{M}^{+}, \mathrm{Au}=197\right] . \mathrm{C}_{126} \mathrm{H}_{166} \mathrm{Au}_{4} \mathrm{O}_{2} \mathrm{P}_{4}$ (2624.43): calcd. C 57.66, H 6.38; found: C 56.88, H 6.31.

Preparation of Compound 11: Compound A (2.83 g, $7.5 \mathrm{mmol})$ was added to a stirred suspension of 2,3,6,7,10,11-hexabromotriphenylene $(0.702 \mathrm{~g}, 1 \mathrm{mmol}), \mathrm{PdCl}_{2}\left(\mathrm{PPh}_{3}\right)_{2}(70 \mathrm{mg}, 0.1 \mathrm{mmol}), \mathrm{CuI}$ (19 mg, $0.1 \mathrm{mmol})$, and $\mathrm{PPh}_{3}(131 \mathrm{mg}, 0.57 \mathrm{mmol})$ in $\mathrm{THF} / \mathrm{Et}_{3} \mathrm{~N}$ $(50 \mathrm{~mL}, 1: 1)$ under nitrogen. The mixture was stirred at $100^{\circ} \mathrm{C}$ for $48 \mathrm{~h}$. After cooling to room temperature, the solvent was removed and the resulting residue was extracted with THF $(3 \times 10 \mathrm{~mL})$. The solvent was removed under vacuum and excess $\mathbf{A}$ was washed with hexanes $(2 \times 10 \mathrm{~mL})$ and ethyl alcohol $(2 \times 10 \mathrm{~mL})$ to give a yellow solid (1.74 g, 85\%). Spectroscopic data of 11: ${ }^{1} \mathrm{H}$ NMR ([D $]$ THF): $\delta=8.99\left(\mathrm{~s}, 6 \mathrm{H}\right.$, triphenylene), $7.65\left(\mathrm{~d},{ }^{3} J_{\mathrm{H}-\mathrm{H}}=8.3 \mathrm{~Hz}, 2 \mathrm{H}, \mathrm{C}_{6} \mathrm{H}_{4}\right)$, $7.55\left(\mathrm{~d},{ }^{3} J_{\mathrm{H}-\mathrm{H}}=8.3 \mathrm{~Hz}, 12 \mathrm{H}, \mathrm{C}_{6} \mathrm{H}_{4}\right), 1.19$ (m, $126 \mathrm{H}$, TIPS) ppm. ${ }^{13} \mathrm{C} \mathrm{NMR}\left(\left[\mathrm{D}_{8}\right] \mathrm{THF}\right): \delta=133.1,132.5,129.8,128.6,125.7,124.6$, $124.3(\mathrm{Ph}), 108.1,95.1,93.3,91.3(\mathrm{C} \equiv \mathrm{C}), 19.2\left(\mathrm{CH}_{3}\right), 12.4(\mathrm{CH})$ ppm. IR $\left(\mathrm{KBr}, \mathrm{cm}^{-1}\right): \tilde{v}=2144\left(v_{\mathrm{C} \equiv \mathrm{C}}\right)$. MALDI-TOF-MS (DHB): $m / z=1913.6\left[\mathrm{M}^{+}+2\right] . \mathrm{C}_{132} \mathrm{H}_{156} \mathrm{Si}_{6}$ (1191.16): calcd. C 82.96, $\mathrm{H}$ 8.23; found $\mathrm{C} 83.06, \mathrm{H} 8.31$.

Preparation of Compound 12: A mixture of 11 (1.74 g, $0.85 \mathrm{mmol})$ and $n \mathrm{Bu}_{4} \mathrm{NF}(10.2 \mathrm{~mL}, 1 \mathrm{M}$ in THF) in THF $(20 \mathrm{~mL})$ was stirred at $45{ }^{\circ} \mathrm{C}$ overnight. The solvent was removed under vacuum and EtOH $(50 \mathrm{~mL})$ was added to give yellow solid which was filtered and dried under vacuum to give 12 (907 mg, 99\%). Spectroscopic data of 12: ${ }^{1} \mathrm{H}$ NMR ([D $\left.\left.{ }_{8}\right] \mathrm{THF}\right): \delta=8.91$ (s, $6 \mathrm{H}$, triphenylene), $7.61\left(\mathrm{~d},{ }^{3} J_{\mathrm{H}-\mathrm{H}}=8.1 \mathrm{~Hz}, 12 \mathrm{H}, \mathrm{C}_{6} \mathrm{H}_{4}\right), 7.51\left(\mathrm{~d},{ }^{3} J_{\mathrm{H}-\mathrm{H}}=8.1 \mathrm{~Hz}, 12\right.$ $\left.\mathrm{H}, \mathrm{C}_{6} \mathrm{H}_{4}\right), 3.77(\mathrm{C} \equiv \mathrm{CH}) \mathrm{ppm} .{ }^{13} \mathrm{C}$ NMR $\left(\left[\mathrm{D}_{8}\right] \mathrm{THF}\right): \delta=133.1$, 132.6, 129.3, 128.1, 125.5, 124.6, $124.5(\mathrm{Ph}), 94.9,91.4,83.9,81.1$ $(\mathrm{C} \equiv \mathrm{C}) \mathrm{ppm}$. IR $\left(\mathrm{KBr}, \mathrm{cm}^{-1}\right): \tilde{v}=3286\left(v_{\mathrm{H}-\mathrm{C} \equiv}\right), 2205\left(v_{\mathrm{C} \equiv \mathrm{C}}\right)$. Mass (FAB): $m / z=974\left[\mathrm{M}^{+}+1\right]$. HRMS cacld for $\mathrm{C}_{78} \mathrm{H}_{36}: 973.2896$; found 973.2913. $\mathrm{C}_{78} \mathrm{H}_{36}$ (973.12): calcd. C 96.27, H 3.73; found C 963.21, H 3.71.

Preparation of Complex 13: trans- $\mathrm{Pd}\left(\mathrm{PBu}_{3}\right)_{2} \mathrm{Cl}_{2}(174 \mathrm{mg}, 0.3 \mathrm{mmol})$ was dissolved in $\mathrm{Et}_{2} \mathrm{NH}(10 \mathrm{~mL})$ containing $\mathrm{CuCl}(2 \mathrm{mg})$. Compound $12(49 \mathrm{mg}, 0.05 \mathrm{mmol})$ in THF $(10 \mathrm{~mL})$ was added and the reaction mixture stirred overnight at room temperature under nitrogen. The solvent was then removed under reduced pressure. The residue was extracted with diethyl ether/hexanes (1:1), the resulting solution was dried with anhydrous $\mathrm{MgSO}_{4}$ following by filtration using Celite. The filtrate was concentrated under reduced pressure and passed through a short column of basic aluminum oxide using petroleum ether (boiling range $40-65^{\circ} \mathrm{C}$ ) as the eluent to remove excess trans- $\mathrm{Pd}\left(\mathrm{PBu}_{3}\right)_{2} \mathrm{Cl}_{2}$. The product 13 was eluted with EtOAc and the solvent was removed by rotary evaporator to give a pale yellow solid identified as 13 (159 mg, 75\% yield). Spectroscopic data of 13: ${ }^{31} \mathrm{P}$ NMR $\left(\mathrm{CD}_{2} \mathrm{Cl}_{2}\right): \delta=10.67 \mathrm{ppm} .{ }^{1} \mathrm{H} \mathrm{NMR}$ $\left(\mathrm{CD}_{2} \mathrm{Cl}_{2}\right): \delta=8.84\left(\mathrm{~s}, 6 \mathrm{H}\right.$, triphenylene), $7.55\left(\mathrm{~d},{ }^{3} J_{\mathrm{H}-\mathrm{H}}=8.2 \mathrm{~Hz}\right.$, $\left.12 \mathrm{H}, \mathrm{C}_{6} \mathrm{H}_{4}\right), 7.29\left(\mathrm{~d},{ }^{3} J_{\mathrm{H}-\mathrm{H}}=8.2 \mathrm{~Hz}, 12 \mathrm{H}, \mathrm{C}_{6} \mathrm{H}_{4}\right), 1.97-1.91(\mathrm{~m}$, $\left.36 \mathrm{H}, \mathrm{CH}_{2}\right), 1.60-1.44\left(\mathrm{~m}, 72 \mathrm{H}, \mathrm{CH}_{2}\right), 0.95\left(\mathrm{t},{ }^{3} J_{\mathrm{H}-\mathrm{H}}=7.2 \mathrm{~Hz}, 54\right.$
$\left.\mathrm{H}, \mathrm{CH}_{3}\right) \mathrm{ppm} .{ }^{13} \mathrm{C} \mathrm{NMR}\left(\mathrm{CD}_{2} \mathrm{Cl}_{2}\right): \delta=132.0,131.3,129.4,129.2$, 128.0, 125.4, $120.1(\mathrm{Ph}), 106.6\left(\mathrm{t},{ }^{3} J_{\mathrm{C}-\mathrm{P}}=5.5 \mathrm{~Hz}, \mathrm{C} \beta\right), 102.7(\mathrm{t}$, $\left.{ }^{2} J_{\mathrm{C}-\mathrm{P}}=15.7 \mathrm{~Hz}, \mathrm{C} \alpha\right), 95.5,89.5(\mathrm{C} \equiv \mathrm{C}), 27.0\left(\mathrm{~s}, \mathrm{CH}_{2}\right), 25.0(\mathrm{t}$, $\left.J_{\mathrm{C}-\mathrm{P}}=6.6 \mathrm{~Hz}, \mathrm{CH}_{2}\right), 23.5\left(\mathrm{t}, J_{\mathrm{C}-\mathrm{P}}=6.6 \mathrm{~Hz}, \mathrm{CH}_{2}\right), 14.2\left(\mathrm{~s}, \mathrm{CH}_{3}\right)$ ppm. IR $\left(\mathrm{KBr}, \mathrm{cm}^{-1}\right): \tilde{v}=2205,2103\left(v_{\mathrm{C} \equiv \mathrm{C}}\right) \cdot \mathrm{C}_{222} \mathrm{H}_{354} \mathrm{Cl}_{6} \mathrm{P}_{12} \mathrm{Pd}_{6}$ (4246.11): calcd. C 62.80, H 8.40; found C 62.65, H 8.51.

Preparation of Complex 14: A mixture of $\mathbf{1 3}$ (49 mg, $0.05 \mathrm{mmol})$, $\mathrm{NaOH}(36 \mathrm{mg}, 0.9 \mathrm{mmol})$ in $\mathrm{EtOH}(2 \mathrm{~mL})$ and $\mathrm{Au}\left(\mathrm{PCy}_{3}\right) \mathrm{Cl}$ $(154 \mathrm{mg}, 0.3 \mathrm{mmol})$ in THF $(10 \mathrm{~mL})$ was stirred at room temperature under nitrogen for $3 \mathrm{~h}$. The solvent was then removed, and then the residue was washed with $\mathrm{EtOH} / \mathrm{H}_{2} \mathrm{O}(1: 1,10 \mathrm{~mL})$ and acetone to give a yellow solid (153 $\mathrm{mg}, 80 \%$ yield). Spectroscopic data of 14: ${ }^{31} \mathrm{P} \mathrm{NMR}\left(\mathrm{CDCl}_{3}\right): \delta=56.86 \mathrm{ppm} .{ }^{1} \mathrm{H} \mathrm{NMR}\left(\mathrm{CDCl}_{3}\right): \delta=$ $8.73\left(\mathrm{~s}, 6 \mathrm{H}\right.$, triphenylene), $7.52\left(\mathrm{~d},{ }^{3} J_{\mathrm{H}-\mathrm{H}}=8.5 \mathrm{~Hz}, 12 \mathrm{H}, \mathrm{C}_{6} \mathrm{H}_{4}\right)$, $7.48\left(\mathrm{~d},{ }^{3} J_{\mathrm{H}-\mathrm{H}}=8.5 \mathrm{~Hz}, 12 \mathrm{H}, \mathrm{C}_{6} \mathrm{H}_{4}\right), 2.02-1.24\left(\mathrm{~m}, 180 \mathrm{H}, \mathrm{PC} y_{3}\right)$ ppm. ${ }^{13} \mathrm{C} \mathrm{NMR}\left(\mathrm{CDCl}_{3}\right): \delta=139.7\left(\mathrm{~d},{ }^{2} J_{\mathrm{P}-\mathrm{C}}=132 \mathrm{~Hz}, \mathrm{AuC} \equiv \mathrm{C}\right)$, 132.3, 131.4, 128.5, 127.2, 125.7, 124.9, $120.9(\mathrm{Ph}), 103.5\left(\mathrm{~d},{ }^{3} J_{\mathrm{P}-\mathrm{C}}\right.$ $=24 \mathrm{~Hz}, \mathrm{AuC} \equiv C), 95.0,89.4,(\mathrm{C} \equiv \mathrm{C}), 33.2\left(\mathrm{~d},{ }^{1} J_{\mathrm{P}-\mathrm{C}}=28 \mathrm{~Hz}\right.$, $\left.C y_{3} \mathrm{P}\right), 30.7\left(\mathrm{~s}, \mathrm{Cy}_{3} \mathrm{P}\right), 27.1$ (d, $\left.{ }^{2} J_{\mathrm{P}-\mathrm{C}}=12 \mathrm{~Hz}, \mathrm{Cy}_{3} \mathrm{P}\right), 25.9\left(\mathrm{~s}, C y_{3} \mathrm{P}\right)$ ppm. IR $\left(\mathrm{KBr}, \mathrm{cm}^{-1}\right): \tilde{v}=2205,2103\left(\mathrm{v}_{\mathrm{C} \equiv \mathrm{C}}\right) \cdot \mathrm{C}_{186} \mathrm{H}_{228} \mathrm{Au}_{6} \mathrm{P}_{6}$ (3831.44): calcd. C 58.31, H 6.00; found C 58.55, H 6.11.

Synthesis of $\mathbf{C l}\left(\mathrm{Et}_{3} \mathbf{P}\right)_{2} \mathbf{P t}\left(\mathrm{C} \equiv \mathrm{CC}_{6} \mathbf{H}_{4} \mathrm{C} \equiv \mathrm{CTIPS}\right)$ (15): trans-Dichlorobis(triethylphosphane)platinum $(201 \mathrm{mg}, 0.40 \mathrm{mmol})$ was treated with compound $\mathbf{A}(113 \mathrm{mg}, 0.4 \mathrm{mmol})$ in the presence of $2 \mathrm{mg}$ of $\mathrm{CuCl}$ as catalyst in $20 \mathrm{~mL}$ of toluene/ $/ \mathrm{Et}_{3} \mathrm{~N}(1: 1)$ at $90^{\circ} \mathrm{C}$. After $24 \mathrm{~h}$ the solvent was removed under vacuum, and the residue was extracted with hexanes. Then the solvent was removed to afford oily residue. The residue was passed through a short column of basic aluminum oxide using hexanes as the eluent to give a colorless oily product 15 (284 mg, 95\% yield). Spectroscopic data of $15:{ }^{31} \mathrm{P}$ NMR $\left(\mathrm{CDCl}_{3}\right): \delta=15.47\left(\mathrm{~s}, J_{\mathrm{Pt}-\mathrm{P}}=2379 \mathrm{~Hz}\right) \mathrm{ppm} .{ }^{1} \mathrm{H} \mathrm{NMR}$ $\left(\mathrm{CDCl}_{3}\right): \delta=7.30\left(\mathrm{~d},{ }^{3} J_{\mathrm{H}-\mathrm{H}}=8.2 \mathrm{~Hz}, 12 \mathrm{H}, \mathrm{C}_{6} \mathrm{H}_{4}\right), 7.13\left(\mathrm{~d},{ }^{3} J_{\mathrm{H}-\mathrm{H}}\right.$ $\left.=8.2 \mathrm{~Hz}, 12 \mathrm{H}, \mathrm{C}_{6} \mathrm{H}_{4}\right), 2.08-1.98\left(\mathrm{~m}, 72 \mathrm{H}, \mathrm{CH}_{2}\right), 1.17\left(\mathrm{dt},{ }^{2} J_{\mathrm{P}-\mathrm{H}}\right.$ $\left.=16.0 \mathrm{~Hz},{ }^{3} J_{\mathrm{H}-\mathrm{H}}=8.0 \mathrm{~Hz}, 108 \mathrm{H}, \mathrm{CH}_{3}\right), 1.10(\mathrm{~m}, 126 \mathrm{H}, \mathrm{TIPS})$ ppm. ${ }^{13} \mathrm{C} \mathrm{NMR}\left(\mathrm{CDCl}_{3}\right): \delta=131.7,130.5,128.8,120.0(\mathrm{Ph}), 107.5$ $(\mathrm{C} \equiv C \mathrm{CSi}), 101.9(\mathrm{~s}, C \equiv \mathrm{CPt}), 90.9(C \equiv \mathrm{CSi}), 85.7\left(\mathrm{t},{ }^{3} J_{\mathrm{C}-\mathrm{P}}=29 \mathrm{~Hz}\right.$, $\mathrm{C} \equiv C \mathrm{Pt}), 18.7\left(\mathrm{CH}_{3}\right), 14.5\left(\mathrm{t},{ }^{3} J_{\mathrm{C}-\mathrm{P}}=18 \mathrm{~Hz}, \mathrm{CH}_{2}\right), 11.3(\mathrm{CH}), 8.0$ $\left(\mathrm{CH}_{3}\right)$ ppm. $\mathrm{MS}(\mathrm{FAB}): m / z=748.3\left[\mathrm{M}^{+}\right](\mathrm{Cl}=35.45)$. $\mathrm{C}_{31} \mathrm{H}_{55} \mathrm{ClP}_{2} \mathrm{PtSi}$ (748.33): calcd. C 49.75, $\mathrm{H} 7.41$; found $\mathrm{C} 49.88, \mathrm{H}$ 7.51.

Preparation of Complex 16: A mixture of 5 (41 mg, $0.05 \mathrm{mmol})$ in THF $(15 \mathrm{~mL})$ and $15(299 \mathrm{mg}, 0.40 \mathrm{mmol})$ in $\mathrm{Et}_{2} \mathrm{NH}(10 \mathrm{~mL})$ was stirred at room temperature in the presence of $\mathrm{CuCl}(2 \mathrm{mg})$ for $24 \mathrm{~h}$. The solvent was then removed under vacuum. The residue was passed through alumina column using $\mathrm{CH}_{2} \mathrm{Cl}_{2}$ /hexanes (1:4) as the eluent to remove excess $\mathbf{1 5}$. The complex $\mathbf{1 6}$ was eluted with EtOAc and the solvent was removed by rotary evaporator to give the yellow solid 16 (211 mg, 83\% yield). Spectroscopic data for 16: ${ }^{31} \mathrm{P}$ NMR $\left(\mathrm{CDCl}_{3}\right): \delta=11.80\left(\mathrm{~s}, J_{\mathrm{Pt}-\mathrm{P}}=2359 \mathrm{~Hz}\right) \mathrm{ppm} .{ }^{1} \mathrm{H}$ NMR $\left(\mathrm{CDCl}_{3}\right): \delta=7.47\left(\mathrm{~d},{ }^{3} J_{\mathrm{H}-\mathrm{H}}=8.2 \mathrm{~Hz}, 12 \mathrm{H}, \mathrm{C}_{6} \mathrm{H}_{4}\right), 7.31\left(\mathrm{~d},{ }^{3} J_{\mathrm{H}-\mathrm{H}}\right.$ $\left.=8.2 \mathrm{~Hz}, 12 \mathrm{H}, \mathrm{C}_{6} \mathrm{H}_{4}\right), 7.25\left(\mathrm{~d},{ }^{3} J_{\mathrm{H}-\mathrm{H}}=8.2 \mathrm{~Hz}, 12 \mathrm{H}, \mathrm{C}_{6} \mathrm{H}_{4}\right), 7.18$ $\left(\mathrm{d},{ }^{3} J_{\mathrm{H}-\mathrm{H}}=8.2 \mathrm{~Hz}, 12 \mathrm{H}, \mathrm{C}_{6} \mathrm{H}_{4}\right), 2.22-2.12\left(\mathrm{~m}, 72 \mathrm{H}, \mathrm{CH}_{2}\right), 1.22$ $\left(\mathrm{dt},{ }^{2} J_{\mathrm{P}-\mathrm{H}}=16.0 \mathrm{~Hz},{ }^{3} J_{\mathrm{H}-\mathrm{H}}=8.0 \mathrm{~Hz}, 108 \mathrm{H}, \mathrm{CH}_{3}\right), 1.10(\mathrm{~m}, 126 \mathrm{H}$, TIPS) ppm. ${ }^{13} \mathrm{C} \mathrm{NMR}\left(\mathrm{CDCl}_{3}\right): \delta=131.7,131.5,130.9,130.6$, $129.3,128.8,127.0,119.8,119.5(\mathrm{Ph}), 112.0\left(\mathrm{t},{ }^{2} J_{\mathrm{C}-\mathrm{P}}=28 \mathrm{~Hz}\right.$, $\mathrm{C} \equiv C \mathrm{Pt}), 110.8\left(\mathrm{t},{ }^{2} J_{\mathrm{C}-\mathrm{P}}=28 \mathrm{~Hz}, \mathrm{C} \equiv C \mathrm{Pt}\right), 110.0(C \equiv \mathrm{CPt}), 109.9$ $(C \equiv \mathrm{CPt}), 107.6,99.9,90.8,88.3(\mathrm{C} \equiv \mathrm{C}), 18.7\left(\mathrm{CH}_{3}\right), 16.4\left(\mathrm{t},{ }^{3} J_{\mathrm{C}-\mathrm{P}}\right.$ $\left.=18 \mathrm{~Hz}, \mathrm{CH}_{2}\right), 11.3(\mathrm{CH}), 8.3\left(\mathrm{CH}_{3}\right)$ ppm. IR $\left(\mathrm{KBr}, \mathrm{cm}^{-1}\right): \tilde{v}=$ 2093, 2195 ( $\left.v_{\mathrm{C} \equiv \mathrm{C}}\right) \cdot \mathrm{C}_{252} \mathrm{H}_{354} \mathrm{P}_{12} \mathrm{Pt}_{6} \mathrm{Si}_{6}$ (5094.17): calcd. C 59.41, H 7.00; found C 59.37, H 7.02.

Preparation of Complex 17: Complex 16 (211 mg, $0.041 \mathrm{mmol})$ was dissolved in THF $(10 \mathrm{~mL})$, and $n \mathrm{Bu}_{4} \mathrm{NF}(0.4 \mathrm{~mL}, 1 \mathrm{M}$ in THF) was 
added. The mixture was stirred at room temperature for $2 \mathrm{~h}$ and then the solvent was removed under vacuum. The residue was purified by washing with EtOH to afford the deprotected alkyne $\mathbf{1 7}$ as yellow solid (171 mg, 99\% yield). Spectroscopic data for $\mathbf{1 7}$ are as follows: ${ }^{31} \mathrm{P}$ NMR $\left(\mathrm{CDCl}_{3}\right): \delta=11.77\left(J_{\mathrm{Pt}-\mathrm{P}}=2359 \mathrm{~Hz}\right) \mathrm{ppm} .{ }^{1} \mathrm{H}$ $\operatorname{NMR}\left(\mathrm{CDCl}_{3}\right): \delta=7.47\left(\mathrm{~d},{ }^{3} J_{\mathrm{H}-\mathrm{H}}=8.2 \mathrm{~Hz}, 12 \mathrm{H}, \mathrm{C}_{6} \mathrm{H}_{4}\right), 7.32(\mathrm{~d}$, $\left.{ }^{3} J_{\mathrm{H}-\mathrm{H}}=8.2 \mathrm{~Hz}, 12 \mathrm{H}, \mathrm{C}_{6} \mathrm{H}_{4}\right), 7.25\left(\mathrm{~d},{ }^{3} J_{\mathrm{H}-\mathrm{H}}=8.2 \mathrm{~Hz}, 12 \mathrm{H}, \mathrm{C}_{6} \mathrm{H}_{4}\right)$, $7.19\left(\mathrm{~d},{ }^{3} J_{\mathrm{H}-\mathrm{H}}=8.2 \mathrm{~Hz}, 12 \mathrm{H}, \mathrm{C}_{6} \mathrm{H}_{4}\right), 3.09(\mathrm{~s}, \mathrm{C} \equiv \mathrm{CH}), 2.19$ $2.14\left(\mathrm{~m}, 72 \mathrm{H}, \mathrm{CH}_{2}\right), 1.22\left(\mathrm{dt}, J_{\mathrm{P}-\mathrm{H}}=16.0 \mathrm{~Hz}, J_{\mathrm{H}-\mathrm{H}}=8.0 \mathrm{~Hz}, 108\right.$ $\left.\mathrm{H}, \mathrm{CH}_{3}\right)$ ppm. ${ }^{13} \mathrm{C} \mathrm{NMR}\left(\mathrm{CDCl}_{3}\right): \delta=131.8,131.5,130.9,130.7$, 129.4, 127.0, 119.5, $118.2(\mathrm{Ph}), 112.0\left(\mathrm{t},{ }^{2} J_{\mathrm{C}-\mathrm{P}}=30 \mathrm{~Hz}, \mathrm{C} \equiv C \mathrm{Pt}\right)$, $111.2\left(\mathrm{t},{ }^{2} J_{\mathrm{C}-\mathrm{P}}=30 \mathrm{~Hz}, \mathrm{C} \equiv C \mathrm{Pt}\right), 110.0(C \equiv \mathrm{CPt}), 109.9(C \equiv \mathrm{CPt})$, 107.6, 99.9, 88.2, $84.1(\mathrm{C} \equiv \mathrm{C}), 77.2(\mathrm{C} \equiv C \mathrm{H}), 16.4\left(\mathrm{t}, J_{\mathrm{C}-\mathrm{P}}=18 \mathrm{~Hz}\right.$, $\left.\mathrm{CH}_{2}\right), 8.3\left(\mathrm{CH}_{3}\right)$ ppm. IR $\left(\mathrm{KBr}, \mathrm{cm}^{-1}\right): \tilde{v}=3286\left(v_{\mathrm{H}-\mathrm{C} \equiv}\right), 2185$, $2093\left(v_{\mathrm{C} \equiv \mathrm{C}}\right) . \mathrm{C}_{198} \mathrm{H}_{234} \mathrm{P}_{12} \mathrm{Pt}_{6}$ (4156.13): calcd. C 57.22, H 5.67; found C 57.47, H 5.82 .

Preparation of Complex 18: To a mixture of 17 (20 mg, $\left.4.8 \times 10^{-3} \mathrm{~mL}\right)$ and $\mathrm{Au}\left(\mathrm{PCy}_{3}\right) \mathrm{Cl}(15 \mathrm{mg}, 0.029 \mathrm{mmol})$ in $\mathrm{THF}$ $(10 \mathrm{~mL})$ was added excess $\mathrm{NaOH}(2 \mathrm{mg}, 0.048 \mathrm{mmol})$ in EtOH $(1 \mathrm{~mL})$. The mixture was stirred at room temperature for $3 \mathrm{~h}$. The solvent was removed under vacuum and the residue was washed with $\mathrm{EtOH} / \mathrm{H}_{2} \mathrm{O}(1: 1,10 \mathrm{~mL})$ and acetone to give a yellow solid (29 mg, 86\% yield). Spectroscopic data for 18 : ${ }^{31} \mathrm{P}$ NMR $\left(\mathrm{CDCl}_{3}\right)$ : $\delta=56.91\left(\mathrm{Cy}_{3} \mathrm{PAu}\right), 11.76\left(J_{\mathrm{Pt}-\mathrm{P}}=2366 \mathrm{~Hz}\right) \mathrm{ppm} .{ }^{1} \mathrm{H} \mathrm{NMR}$ $\left(\mathrm{CDCl}_{3}\right): \delta=7.45\left(\mathrm{~d},{ }^{3} J_{\mathrm{H}-\mathrm{H}}=8.2 \mathrm{~Hz}, 12 \mathrm{H}, \mathrm{C}_{6} \mathrm{H}_{4}\right), 7.32\left(\mathrm{~d},{ }^{3} J_{\mathrm{H}-\mathrm{H}}\right.$ $\left.=7.8 \mathrm{~Hz}, 12 \mathrm{H}, \mathrm{C}_{6} \mathrm{H}_{4}\right), 7.23\left(\mathrm{~d},{ }^{3} J_{\mathrm{H}-\mathrm{H}}=7.8 \mathrm{~Hz}, 12 \mathrm{H}, \mathrm{C}_{6} \mathrm{H}_{4}\right), 7.10$ $\left(\mathrm{d},{ }^{3} J_{\mathrm{H}-\mathrm{H}}=7.8 \mathrm{~Hz}, 12 \mathrm{H}, \mathrm{C}_{6} \mathrm{H}_{4}\right), 2.17-1.15\left(\mathrm{~m}, 360 \mathrm{H}, \mathrm{PCy}_{3}\right.$ and $\left.\mathrm{PEt}_{3}\right)$ ppm. IR $\left(\mathrm{KBr}, \quad \mathrm{cm}^{-1}\right): \tilde{v}=2185,2083 \quad\left(v_{\mathrm{C} \equiv \mathrm{C}}\right)$. $\mathrm{C}_{306} \mathrm{H}_{426} \mathrm{Au}_{6} \mathrm{P}_{18} \mathrm{Pt}_{6}$ (7014.45): calcd. C 52.40, $\mathrm{H}$ 6.12; found $\mathrm{C}$ 52.68, H 7.20.

\section{Acknowledgments}

Financial support provided by the National Science Council of Taiwan is grateful acknowledged. Funding for the Instrumentation Facility of the Department of Chemistry of NTU has also been provided in part by the National Science Council of Taiwan.

[1] a) S. Szafert, J. A. Gladysz, Chem. Rev. 2003, 103, 4175-4205; b) V. W.-W. Yam, Acc. Chem. Res. 2002, 35, 555-563; c) U. H. F. Bunz, Y. Rubin, Y. Tobe, Chem. Soc. Rev. 1999, 28, 107-119; d) U. H. F. Bunz, Angew. Chem. Int. Ed. Engl. 1996, 35, 969-971; e) J. Manna, K. D. John, M. D. Hopkins, $A d v$. Organomet. Chem. 1995, 38, 79-154.

[2] a) C. C. Frazier, S. Guha, W. P. Chen, P. M. Cockerham, P. L. Porter, E. A. Chauchard, C. H. Lee, Polymer 1987, 28, 553555; b) C. C. Frazier, S. Guha, P. L. Porter, P. M. Cockerham, in: Nonlinear Optical Properties of Organic Materials; Proc. SPIE No. 971; The International Society for Optical Enginnering: Washington, DC, 1988, p. 186; c) C. C. Frazier, E. A. Chauchard, P. M. Cockerham, P. L. Porter, Mater. Res. Soc. Symp. Proc. 1988, 109, 323-328; d) S. Guha, C. C. Frazier, P. L. Porter, K. Kang, S. Finberg, Opt. Lett. 1989, 14, 952-954; e) A. P. Davey, D. J. Cardin, H. J. Byrne, W. J. Blau, in: Organic Molecules for Nonlinear Optics and Photonics (Eds.: J. Messier, F. Kajzar, P. Prasad, Eds.); NATO ASI Series E, vol. 194; Kluwer Academic: Dordrecht, 1991; p. 391; f) W. J. Blau, H. J. Byrne, D. J. Cardin, A. P. Davey, J. Mater. Chem. 1991, 1, 245249; g) A. P. Davey, H. Page, W. J. Blau, H. J. Byrne, H. J. Byrne, D. J. Cardin, Synth. Met. 1993, 57, 3980-3985.

[3] H. Nishihara, in: Handbook of Organic Conductive Molecules and Polymers, vol. 2: Conductive Polymers: Synthesis and Elec- trical Properties (Ed.: H. S. Nalwa), Wiley: New York, 1997; p. 799.

[4] V. W. W. Yam, K. K. W. Lo, K. M. C. Wong, J. Organomet. Chem. 1999, 578, 3.

[5] a) S. Takahashi, E. Murata, M. Kariya, K. Sonogashira, N. Hagihara, Macromolecules 1979, 12, 1016-1018; b) S. Takahashi, E. Murata, Y. Takai, K. Sonogashira, N. Hagihara, Mol. Cryst. Liq. Cryst. 1981, 72, 101-105.

[6] a) K. Sonogashira, S. Takahashi, N. Hagihara, Macromolecules 1977, 10, 879-880; b) S. Takahashi, M. Kariya, T. Yakate, K. Sonogashira, N. Hagihara, Macromolecules 1978, 11, 1063 1066.

[7] S. J. Davies, B. F. G. Johnson, M. S. Khan, J. Lewis, J. Chem. Soc. Chem. Commun. 1991, 187-188.

[8] S. Leininger, P. J. Stang, S. Huang, Organometallics 1998, 17, 3981-3987.

[9] a) K. Onitsuka, M. Fujimoto, N. Ohshiro, S. Takahashi, Angew. Chem. Int. Ed. 1999, 38, 689-692; b) N. Ohshiro, F. Takei, K. Onitsuka, S. Takahashi, Chem. Lett. 1996, 25, 871-872; c) K. Onitsuka, A. Shimizu, S. Takahashi, Chem. Commun. 2003, 280-281; d) K. Nitsuka, M. Fujimoto, H. Itajima, N. Ohshiro, F. Takei, S. Takahashi, Chem. Eur. J. 2004, 10, 6433-6446.

[10] a) V. W. W. Yam, C. H. Tao, L. Zhang, K. M. C. Wong, K. K. Cheung, Organometallics 2001, 20, 453-459; b) V. W. W. Yam, L. Zhang, C. H. Tao, K. M. C. Wong, K. K. Cheung, J. Chem. Soc. Dalton Trans. 2001, 1111-1116; c) C. H. Tao, N. Zhu, V. W. W. Yam, Chem. Eur. J. 2005, 11, 1647-1657.

[11] a) R. Diercks, J. C. Armstrong, R. Boese, K. P. C. Vollhardt, Angew. Chem. Int. Ed. Engl. 1986, 25, 268-269; b) R. Böse, J. R. Green, J. Mittendorf, D. L. Möhler, K. P. C. Vollhardt, Angew. Chem. Int. Ed. Engl. 1992, 31, 1643-1645.

[12] B. Kayser, J. Altman, H. Nöth, J. Knizek, W. Beck, Eur. J. Inorg. Chem. 1998, 1791-1798.

[13] O. Lavastre, L. Ollivier, P. H. Dixneuf, Tetrahedron 1996, 52, $5495-5504$.

[14] K. Sonogashira, Comprehensive Organic Synthesis (Eds.: B. M. Trost, I. Fleming); Pergamon: New York, 1991; vol. 3, pp. 521549.

[15] T. M. Pappenfus, K. R. Mann, Org. Lett. 2002, 4, 3043-3046.

[16] G. Jia, R. J. Puddephatt, J. D. Scott, J. J. Vitta1, Organometallics 1993, 12, 3655-3665.

[17] H.-Y. Chao, W. Lu, Y. Li, M. C. W. Chan, C.-M. Che, K.-K. Cheung, N. Zhu, J. Am. Chem. Soc. 2002, 124, 14696-14706.

[18] K. Onitsuka, T. Joh, S. Takahashi, Bull. Chem. Soc. Jpn. 1992, $65,1179-1181$.

[19] A. Sebald, C. Stader, B. Wrackmeyer, W. Bensch, J. Organomet. Chem. 1986, 311, 233-242.

[20] K. Kondo, S. Yasuda, S. Tohoru, M. Miya, J. Chem. Soc. Chem. Commun. 1995, 55-56.

[21] H. Li, D. R. Powell, R. K. Hayashi, R. West, Macromolecules 1998, 31, 52-58.

[22] D. A. Roberts, W. R. Mason, G. L. Geoffroy, Inorg. Chem. 1981, 20, 789-796.

[23] a) C, L. Choi, Y. F. Cheng, C. Yip, D. L. Phillips, V. W. W. Yam, Organometallics 2000, 19, 3192-3196; b) H. Masai, K. Sonogashira, N. Hagihara, Bull. Chem. Soc. Jpn. 1971, 44, 22262230; c) W. M. Kwok, D. L. Phillips, P. K. Y. Yeung, V. W. W. Yam, Chem. Phys. Lett. 1996, 262, 699-708; d) W. M. Kwok, D. L. Phillips, P. K. Y. Yeung, V. W. W. Yam, J. Phys. Chem. A 1997, 101, 9286-9295.

[24] A. K. Al-sáady, C. A. Mcauliffe, R. V. Parish, J. A. Sandbank, Inorg. Synth. 1985, 23, 191-194.

[25] T. Yatabe, M. A. Harbison, J. D. Brand, M. Wagner, K. Müllen, P. Samori, J. P. Rabe, J. Mater. Chem. 2000, 10, 15191525.

[26] A. N. Fleter, Photochem. Photobiol. 1969, 9, 439-444.

[27] M. Rack, B. Hauschel, M. Hanack, Chem. Ber. 1996, 129, 237 242.

Received: May 1, 2006 Published Online: July 28, 2006 